\title{
Expedition 306 summary ${ }^{1}$
}

\author{
Expedition 306 Scientists $^{2}$
}

\begin{abstract}
Chapter contents
Abstract......................

Preface.................. 1

Part A:

Introduction $\ldots \ldots \ldots \ldots \ldots \ldots \ldots$

Background .................. 2

Scientific objectives.............. 3

Relationship to previous

North Atlantic drilling .............

Drilling strategy. .............

Part B:

Introduction $\ldots \ldots \ldots \ldots \ldots \ldots \ldots \ldots$

Background .................. 6

Scientific objectives..............6

Proposed research. . . . . . . . . . . . 7

Operational strategy $\ldots \ldots \ldots \ldots \ldots \ldots \ldots 7$

Principal results...............

Summary and conclusions. . . . . . . . . 14

References................... 16

Figures.................. 20

Table .......................... 29
\end{abstract}

${ }^{1}$ Expedition 306 Scientists, 2006. Expedition 306 summary. In Channell, J.E.T., Kanamatsu, T., Sato, T., Stein, R., Alvarez Zarikian, C.A., Malone, M.J., and the Expedition 303/306 Scientists. Proc. IODP, 303/306: College Station TX (Integrated Ocean Drilling Program Management International, Inc.). doi:10.2204/iodp.proc.303306.109.2006

'Expedition 306 Scientists' addresses.

\section{Abstract}

The overall aim of the North Atlantic paleoceanography study of Integrated Ocean Drilling Program Expedition 306 is to place late Neogene-Quaternary climate proxies in the North Atlantic into a chronology based on a combination of geomagnetic paleointensity, stable isotope, and detrital layer stratigraphies, and in so doing generate integrated North Atlantic millennial-scale stratigraphies for the last few million years. To reach this aim, complete sedimentary sections were drilled by multiple advanced piston coring directly south of the central Atlantic "ice-rafted debris belt" and on the southern Gardar Drift. In addition to the North Atlantic paleoceanography study, a borehole observatory was successfully installed in a new $\sim 180 \mathrm{~m}$ deep hole close to Ocean Drilling Program Site 642, consisting of a circulation obviation retrofit kit to seal the borehole from the overlying ocean, a thermistor string, and a data logger to document and monitor bottom water temperature variations through time.

\section{Preface}

Integrated Ocean Drilling Program (IODP) Expedition 306 is based on two separate proposals entitled (A) "Ice sheet-ocean atmosphere interactions on millennial timescales during the late Neogene-Quaternary using a paleointensity-assisted chronology (PAC) for the North Atlantic" and (B) "Installation of a circulation obviation retrofit kit (CORK) near Hole 642E to document and monitor bottom water temperature variations through time." Since both parts are independent of each other, the introductory sections of the Expedition 306 report (introduction, background, geological setting, and objectives) have been divided into Part A and Part B. Sites U1312, U1313, and U1314 are related to the North Atlantic paleoceanography study (Part A), whereas Site U1315 and the revisited Ocean Drilling Program (ODP) Hole 642E are related to the CORK program (Part B). 
Part A: Ice sheet-ocean atmosphere interactions on millennial timescales during the late Neogene-Quaternary using a PAC for the North Atlantic

\section{Introduction}

Following Expedition 303, Expedition 306 is the second cruise of the North Atlantic paleoceanography study that aims to generate a late Neogene-Quaternary chronostratigraphic template for North Atlantic climate proxies and allow for their correlation at a sub-Milankovitch scale and their export to other parts of the globe by using a PAC. The nine primary drilling locations selected for the North Atlantic paleoceanography study (Fig. F1) are known, either from previous ODP/Deep Sea Drilling Project (DSDP) drilling or from conventional piston cores, to have the following attributes:

- They contain distinct records of millennial-scale environmental variability (in terms of ice sheetocean interactions, deep circulation changes, or sea-surface conditions).

- They provide the requirements for developing a millennial-scale stratigraphy (through geomagnetic paleointensity, oxygen isotopes, microfossils, and regional environmental patterns).

- They document the details of geomagnetic field behavior.

Expedition 303, carried out in October-November 2004, occupied seven precruise sites recovering over $4600 \mathrm{~m}$ of high-quality upper Pliocene-Quaternary sediments (Fig. F1): Sites U1302/U1303 (proposed sites ORPH3A and 2A), U1304 (proposed site GAR2B), U1305, U1306, and U1307 (proposed sites LAB6A, 7A, and 8C), and U1308 (proposed site IRD1A) (see Expedition 303 Preliminary Report [Shipboard Scientific Party, 2005] for additional details).

Results from drilling at Site U1307 (LAB8C) during Expedition 303 established the feasibility of recovering the Pliocene sedimentary section on the Eirik Drift using the advanced piston corer (APC) system. Two holes were drilled at Site U1307 (LAB8C) reaching a maximum depth of 162 meters composite depth (mcd) in the uppermost Gilbert Chronozone $(\sim 3.6 \mathrm{Ma})$. Coring was terminated due to excessive heave when a passing storm system began to affect drilling operations. Proposed Expedition 306 sites on Eirik Drift would have offered the unique opportunity to extend the upper Pliocene-Quaternary record recovered during Expedition 303, back in time to the Miocene (see Expedition 303/306 Scientific Prospectus Addendum [Kanamatsu et al., 2005]).
Based on the Expedition 303/306 Scientific Prospectus (Channell et al., 2004) and the results of Expedition 303, Sites IRD3A and IRD4A and two sites on Eirik Drift were selected to become the primary Expedition 306 sites. Continuous weather observations performed throughout Expedition 306 showed, however, that coring operations on Eirik Drift were not possible at any time due to extremely bad weather conditions in the Labrador Sea. Thus, the alternate Site GAR1B was a primary site instead. In total we lost 10 days due to severe weather conditions during the first part of the expedition. Therefore, only three, instead of the planned four sites related to the North Atlantic paleoceanography study, could be drilled during Expedition 306 (Sites U1312, U1313, and U1314) (Fig. F1).

\section{Background}

The North Atlantic Ocean is undoubtedly one of the most climatically sensitive regions on Earth because the ocean-atmosphere-cryosphere system is prone to mode jumps that are triggered by changes in freshwater delivery to source areas of deepwater formation. During the last glaciation, these abrupt jumps in climate state are manifested by Dansgaard/ Oeschger $(\mathrm{D} / \mathrm{O})$ cycles and Heinrich events in ice and marine sediment cores, respectively. Given the paramount importance of the North Atlantic as a driver of global climate change, we proposed to drill at nine key locations to extend the study of millennial-scale climate variability over the last few million years. The rationale for studying millennial-scale variability in the North Atlantic over the last few million years rather than just the last glacial cycle (recoverable by conventional piston cores) is to reconstruct the long-term evolution of millennial-scale variability in surface temperature, ice sheet dynamics, and thermohaline circulation and to thereby provide clues to the mechanisms responsible for abrupt climate change. For example, the average climate state evolved toward generally colder conditions with larger ice sheets during the PliocenePleistocene. This shift was accompanied by a change in the spectral character of climate proxies, from dominantly 41 to 100 k.y. periods between 920 and 640 ka (Mudelsee and Schulz, 1997; Schmieder et al., 2000). Among the numerous questions to be answered are the following:

- When did Heinrich events first appear in the sedimentary record of the North Atlantic?

- Are they restricted to the 100 k.y. world when ice volume increased substantially? 


\section{Scientific objectives}

\section{Climate-related objectives}

Stratigraphy is the fundamental backbone of our understanding of Earth's history, and stratigraphic resolution is the main factor that limits the timescale of processes that can be studied in the past. SubMilankovitch-scale climate studies face the challenge of finding a stratigraphic method suitable for correlation at this scale (see Crowley, 1999). Even under optimal conditions, chronologies based on $\delta^{18} \mathrm{O}$ are unable to provide sufficient stratigraphic resolution. Within the North Atlantic region, recent improvements in stratigraphic resolution have resulted in a new understanding of the dynamics of millennialscale climate variability over the last 100 k.y. (e.g., van Kreveld et al., 2000; Sarnthein et al., 2000). These stratigraphies have utilized chronologies from the Greenland Summit ice cores (GRIP/GISP2) and the recognition of regional lithostratigraphic linkages such as Heinrich events and higher frequency ice-rafted debris (IRD) layers, ash layers, and susceptibility cycles combined with planktonic/benthic $\delta^{18} \mathrm{O}$, acceleration mass spectrometry (AMS) ${ }^{14} \mathrm{C}$ dates, and geomagnetic paleointensity data (e.g., Bond et al., 1992, 1993, 1999b; McManus et al., 1994; Stoner et al., 1998, 2002; Voelker et al., 1998; Kissel et al., 1999; Laj et al., 2000).

The objective of the expedition is to integrate stable isotope and relative geomagnetic paleointensity data with paleoceanographic proxies, and in so doing generate integrated North Atlantic millennial-scale stratigraphies for the last few million years.

Understanding the mechanisms and causes of abrupt climate change is one of the major challenges in global climate change research today (see Clark et al., 1999) and constitutes a vital initiative of the Initial Science Plan of IODP. Ideally, the best approach to this problem would be to collect records of climate variability from a dense geographic network of sites, but this is impractical in paleoceanographic research. In the absence of dense coverage, the most viable approach is to obtain long, continuous time series from key regions and compare the response and timing of climate change among sensitive regions. Here, we intend to develop PACs to establish the phase relationships among globally distributed millennial-scale records. Building global correlations on millennial timescales is an essential step to defining the underlying mechanisms of abrupt climate change.

A persistent $\sim 1500$ y cycle has been observed for the past $80 \mathrm{k} . \mathrm{y}$. that is apparently independent of glacial or interglacial climate state (Bond et al., 1999b). The millennial-scale cyclicity in the Holocene appears to be mirrored in the last interglacial (marine isotope Stage [MIS] 5e) and is defined by the same petrologic proxies in both interglacials. The presence of this cyclicity in interglacials, and the IRD petrology that defines it, indicates that the cyclicity does not reflect ice sheet instability or changes in calving of coastal glaciers, but rather changes in sources of drifting ice, driven by changes in the size and intensity of the subpolar cyclonic gyre (Bond et al., 1999b). The Holocene cycles reflect a mechanism operating on at least a hemispheric scale (Sirocko et al., 1996; Campbell et al., 1998; deMenocal et al., 2000), indicating that the MIS 5e and Holocene cyclicities have a common origin, possibly related to solar forcing (Bond et al., 2001). The implication is that the $1500 \mathrm{y}$ cycle may have been a dominant feature of the Earth's ocean-atmosphere climate for a very long time. How far back in time does the $\sim 1500$ y cycle extend? Do $\mathrm{D} / \mathrm{O}$ cycles simply represent an amplification of this? Do distinct modes of variability persist through other glacial and interglacial intervals? If so, is the pacing always the same or does millennial-scale variability evolve during the late Pleistocene?

Recently published evidence from earlier interglacials (MIS 11 and 13) in both the subpolar and subtropical North Atlantic suggests that interglacial cyclicity at those times may have had a significantly longer pacing, on the order of $5000 \mathrm{y}$ or more. The interglacial records from MIS 11 and 13 in Oppo et al. (1998) and McManus et al. (1999), for example, show rather sporadic IRD events that, regardless of age model, cannot occur every 1500 y. Similarly, the MIS 11 record from Site 1063 off Bermuda indicates large shifts in benthic $\delta^{13} \mathrm{C}$ on the order of 5-6 k.y. (Poli et al., 2000). In contrast, surface water temperature and deepwater ventilation data from MIS 11 and 13 at Site 980 imply the presence of a 1-2 k.y. pacing (McManus et al., 1999; Oppo et al., 1998), suggesting that the $1500 \mathrm{y}$ cycle may be operating in MIS 11 and in other pre-MIS 5e interglacials. If this is true, then the interglacial climate variability may reflect a persistent, perhaps periodic, process operating continuously within the Earth's climate (rather than red noise resulting from a highly nonlinear climate system).

The best evidence for the $1500 \mathrm{y}$ cycle during interglacials seems to come from IRD proxies that monitor changes in the subpolar gyre in the North Atlantic. Our proposed drilling sites are positioned to monitor such changes. In contrast to ODP Site 980 (Rockall Plateau), the Expeditions 303 and 306 sites are located well within or close to the main presentday routes of iceberg transport into the North Atlantic and therefore are well-suited to capture faint interglacial signals in shifting ocean surface circula- 
tion. If we can connect the $1500 \mathrm{y}$ cycle to paleointensity records, we will have a means of directly comparing both signals with climate records from well outside the North Atlantic.

\section{Geomagnetic-related objectives}

Understanding the changes in the ice sheet-oceanatmosphere system that gave rise to millennial-scale climate changes requires the precise long-distance correlation of ice cores and marine sediment cores. Geomagnetic paleointensity records from marine sediment cores have been shown to contain a global signal suitable for fine-scale correlation (see Meynadier et al., 1992; Guyodo and Valet, 1996; Channell et al., 2000; Stoner et al., 2000, 2002; Laj et al., 2000), at least for the last glacial cycle.

Beyond the range of AMS ${ }^{14} \mathrm{C}$ dating, geomagnetic paleointensity data may provide the only viable means of sub-Milankovitch-scale long-distance correlation. Paleointensity records have been applied to stratigraphic correlation in the Labrador Sea for the last 200 k.y. (Stoner et al., 1998), throughout the North Atlantic for the last 75 k.y. (Laj et al., 2000), and for the Atlantic realm for the last 110 k.y. (Stoner et al., 2000). As variations in geomagnetic paleointensity control atmospheric production of ${ }^{10} \mathrm{Be}$ and ${ }^{36} \mathrm{Cl}$ isotopes and the flux of these isotopes is readily measurable in ice cores, paleointensity records in marine cores provide an independent link between marine sediment and ice core records (e.g., Mazaud et al., 1994). The paleointensity lows at $\sim 40$ and $\sim 65 \mathrm{ka}$ are readily identifiable as highs in ${ }^{10} \mathrm{Be}$ and ${ }^{36} \mathrm{Cl}$ fluxes (Raisbeck et al., 1987; Baumgartner et al., 1998) in the Vostok and GRIP ice cores, respectively. Frank et al. (1997) showed that $10^{4}-10^{5}$ y variability in the ${ }^{10} \mathrm{Be}$ production rate, as determined from globally distributed deep-sea cores over the last 200 k.y., can be matched to sediment paleointensity data. This observation and the similarity of globally distributed paleointensity records indicate that much of the variability in paleointensity records is globally correlative. The few high-resolution paleointensity records available beyond $200 \mathrm{ka}$ also indicate that fine-scale features are correlative. For example, the paleointensity record for the MIS 9-11 interval (300-400 ka) from the Iceland Basin (Sites 983 and 984) can be correlated to the sub-Antarctic South Atlantic (Site 1089) at suborbital (millennial) scale (Stoner et al., 2002).

In addition to the practical use of magnetic field records for correlation of climate records, further drilling of high-sedimentation-rate drift sites impact the "solid Earth" theme of IODP by documenting the spatial and temporal behavior of the geomagnetic field at unprecedented resolution. Such data elucidate processes in the geodynamo controlling secular variation and polarity reversal of the geomagnetic field. Recently derived records of directional secular variation and paleointensity from drift sites (e.g., Legs 162 and 172) have substantially advanced our knowledge of magnetic secular variation, magnetic excursions, and directional/intensity changes at polarity reversal boundaries (see Channell and Lehman, 1997; Channell et al., 1998, 2002; Lund et al., 1998, 2001a, 2001b). Numerous directional magnetic excursions have been observed within the Brunhes Chron at ODP Leg 172 drift sites (Lund et al., 1998, 2001a, 2001b) and in the Matuyama Chron at ODP Leg 162 sites (Channel et al., 2002). These excursions (or brief subchrons) correspond to paleointensity minima and have estimated durations of a few thousand years. From ODP Leg 162 records and records from the Pacific Ocean, it has been suggested that spectral power at orbital frequencies in paleointensity records may reflect a fundamental property of the geodynamo (Channell et al., 1998; Yamazaki, 1999) rather than climate-related contamination of paleointensity records (Guyodo et al., 2000).

There is no doubt that North Atlantic drift sites have revolutionized our understanding of the behavior of the geomagnetic field by providing Brunhes paleomagnetic records of unprecedented resolution. These records can now provide useful constraints for numerical simulations of the geodynamo (e.g., Glatzmaier and Roberts, 1995; Gubbins, 1999; Coe et al., 2000). As a result of these parallel advances, our understanding of the geomagnetic field is on the threshold of substantial progress.

The Expedition 303 and 306 drilling sites provide high-resolution paleomagnetic records extending through the Matuyama Chron (to $\sim 3 \mathrm{Ma}$ ). They will allow us to assess the temporal and spatial variability of the geomagnetic field in the Brunhes Chron and compare these records with reversed polarity records from the Matuyama Chron. Are the characteristics of secular variation different for the two polarity states? Are polarity transition fields comparable for sequential polarity reversals? Does the geomagnetic field exhibit a complete spectrum of behavior from highamplitude secular variation to polarity reversals, which has not hitherto been documented due to lack of high-resolution records?

The non-axial-dipole (NAD) components in the historical field vary on a centennial timescale, and this has been interpreted to indicate similar repeat times in the past (Hulot and Le Mouël, 1994; Hongre et al., 1998). If this is correct, paleointensity records from cores with sedimentation rates less than $\sim 10 \mathrm{~cm} / \mathrm{k} . \mathrm{y}$. are unlikely to record anything but the axial dipole 
field. On the other hand, standing NAD components have been detected in the $5 \mathrm{~m}$.y. time-averaged field, although the distribution of these NAD features remains controversial (Kelley and Gubbins, 1997; Johnson and Constable, 1997; Carlut and Courtillot, 1998). Refinement of time-averaged field models as the paleomagnetic database is augmented will lead to a better grasp of how the nonzonal terms in the time-averaged field may influence paleointensity records.

\section{Relationship to previous North Atlantic drilling}

Prior to Expeditions 303 and 306, two previous ODP legs to the North Atlantic recovered sequences that are continuous and have sedimentation rates high enough to study oceanic variability on subMilankovitch timescales. During Leg 162 four sites were drilled on sediment drifts south of Iceland (Fig. F2). These sequences are yielding invaluable insight into the nature of millennial-scale climate variability in the North Atlantic (Raymo et al., 1998; McManus et al., 1999; Raymo, 1999, 2004; Flower et al., 2000; Kleiven et al., 2003). Similarly, Leg 172 recovered sequences with high deposition rates that are suitable for millennial- and perhaps centennial-scale studies in the northwest Atlantic between $\sim 30^{\circ}$ and $35^{\circ} \mathrm{N}$ (Keigwin et al., 2001; Rio and Arnold, 2002). Given the successes of Legs 162 and 172, why are additional sites needed in the North Atlantic? The sites herein will augment those of Legs 162 and 172 in two fundamental ways. First, most of our sites are located in or close to the North Atlantic "IRD belt," (Fig. F2) where massive iceberg discharges are recorded by coarse layers of IRD that are depleted in planktonic foraminifers and have oxygen isotopic values indicative of reduced sea-surface salinities. Site 980 (from Leg 162) was recovered within the IRD belt, but it is located on its distal northeastern edge and, consequently, lacks the strong sea-surface response to millennial-scale IRD events that are so well displayed to the south and west. Second, the depth distribution of the proposed sites (2273-3884 meters below sea level [mbsl]) are ideal for monitoring millennial-scale changes in the production of North Atlantic Deep Water (NADW). Leg 162 sites span 1650-2170 mbsl and provide the intermediatedepth end-member for studies of the formation of Glacial North Atlantic Intermediate Water (GNAIW). Leg 172 drift sites provide a relatively complete depth transect spanning 1291-4595 mbsl. The Expedition 303 and 306 sites will unify the record of millennial-scale variability in the North Atlantic by bridging the "gap" between Legs 162 and 172. The sites will also expand the geographic range of sites needed to distinguish between latitudinal changes in the mixing zone between southern and northern source waters and changes due to vertical migration of water mass boundaries (Flower et al., 2000).

Data and modeling studies point to changes in the modes of NADW formation as one of the principal factors driving millennial-scale climate change in the high-latitude North Atlantic and Europe (for review, see Alley et al., 1999). Expedition 303 sites (Fig. F1) are distributed so that they monitor the major deepwater end-members of NADW: NorwegianGreenland Sea Water (Site U1304) and Labrador Seawater (Sites U1305-U1307) as well as the NADW mixture (Site U1302/U1303). Alley et al. (1999) discussed three distinct modes of thermohaline circulation in the North Atlantic: modern (M), glacial (G), and Heinrich $(\mathrm{H})$. The modern mode is marked by deepwater formation in the Nordic seas and North Atlantic where the three end-members mix to form NADW. In the glacial mode, deepwater formation is suppressed in the Nordic seas and GNAIW forms farther south in the North Atlantic. In the Heinrich mode, both deep- and intermediate-water formation is greatly reduced. Together with the depth transects drilled during Legs 162 and 172, the Expedition 303 and 306 sites will permit monitoring deep and intermediate-water formation during all three modes of formation.

\section{Drilling strategy}

The high-resolution stratigraphic goals require high sedimentation rates $(>5 \mathrm{~cm} / \mathrm{k} . \mathrm{y}$.) at the chosen sites, as well as complete and undisturbed recovery of the stratigraphic sequence. The drilling strategy remained the same as on Expedition 303 and consisted of the use of the APC system in three or more holes at each site to ensure complete and undisturbed recovery of the stratigraphic section. We used the "drillover" strategy employed during Leg 202 to maximize APC recovery and penetration. Traditionally, the depth limit of APC coring is controlled by the overpull required to retrieve the core barrel. In cases where the full APC stroke is achieved but excessive force is required to retrieve the core barrel (often the limit of APC penetration), the drillover strategy entails advance of the rotary bit to free the APC barrel. APC coring was generally terminated when the pressure gauge on the rig floor indicated that full APC stroke could no longer be achieved. Because of the pivotal role of magnetic studies in the objectives of the proposal, nonmagnetic core barrels were generally used. However, due to the relative fragility and high cost of nonmagnetic core barrels, the normal 
steel magnetic barrels were used after the initiation of drillover.

Two factors influenced the decision to terminate holes at the limit of the APC, and therefore not to utilize extended core barrel (XCB) technique:

1. The increase in drilling disturbance associated with the $\mathrm{XCB}$, particularly in the upper part of the $\mathrm{XCB}$ section, has not been conducive to the generation of high-resolution PAC chronologies. Poor recovery and "biscuiting" are common in poorly consolidated lithologies recovered by XCB.

2. At all locations, other than Site U1314, the deeper stratigraphic section has been sampled in the region during DSDP Leg 94.

\section{Part B: Installation of a CORK close to ODP Site 642 to document and monitor bottom water temperature variations through time}

\section{Introduction}

The northern North Atlantic is the primary deep ventilator of the oceans, and it is now recognized that production of deep water in the northern North Atlantic is intimately related to the global climate (Broecker, 1987; Dickson, 1997; Wood et al., 1999). Changes in the production of NADW may be the result of, or lead to, regional or global climatic changes. Unfortunately there is a lack of long-term observations, and those that do extend back in time are concentrated at the surface or near-surface. Hydrographic time series from the North Atlantic, though sparse and sporadic, show natural variability on timescales of decades to centuries (Wunsch, 1992). In the deep ocean the few observations that do exist show variability on similar timescales and at large spatial scales. Oceanographic observations indicate that the thermohaline structure of the North Atlantic has changed over the past 20 to $30 \mathrm{y}$, indicating the presence of significant variations in bottom water temperature (BWT) (Roemmich and Wunsch, 1984; Antonov, 1993).

\section{Background}

It is hypothesized that subbottom temperaturedepth profiles can be used to construct BWT histories at timescales on the order of decades to a century. The conductive thermal regime of oceanic crust comprises the superposition of two processes: the outward flow of heat from the Earth's deep interior, and perturbations to the deep regime by changes of BWT at the seafloor. The latter effects operate on a relatively short timescale (decades, centuries, and millennia), whereas the former process operates on a geologic timescale, with secular changes taking place over millions of years. In the context of the shortterm BWT perturbations, the outward flow of heat from the interior is seen as a quasi steady-state process. Because oceanic sediments have a low thermal diffusivity, changes in BWT diffuse slowly downward by conduction, perturbing the background thermal regime. These measurable anomalies are a direct thermophysical consequence of BWT variations, and as such are a straightforward measure of temperature, not a proxy. Resolution analysis indicates that $100 \mathrm{y}$ of temperature change is potentially recoverable from high-precision temperature-depth logs in boreholes $200 \mathrm{~m}$ deep. If this hypothesis is correct and because ocean bottom sediments continuously record changes in BWT, it is theoretically possible to reconstruct BWT histories anywhere in the ocean.

Site 642 (Fig. F3) represents an ideal candidate to test this hypothesis for two reasons. First, it is located near Ocean Weather Ship Station Mike, which has been in continuous operation over the last $50 \mathrm{y}$. Weekly temperature and salinity measurements at depths of greater than $2000 \mathrm{~m}$ have been made since 1948 (Gammelsrød et al., 1992). These measurements represent the longest homogeneous time series from the deep ocean, and they will be used to check the efficacy of our measurements and analysis as well as to provide a direct test of our hypothesis. Second, it is located on the eastern margin of the Norwegian Sea (Fig. F3), a climatically sensitive area that records the changing hydrographic character and horizontal exchange of deep water from the Greenland Sea, Arctic Ocean, and Norwegian Sea. As such, BWT histories will yield insight into the complex interplay between these important water masses.

\section{Scientific objectives}

The primary objectives of this study are:

- To document the ability to recover BWT histories from temperature-depth profiles. The possibility to reconstruct BWT histories with sufficient resolution creates the potential for transects of such measurements across climatologically important gateways such as the Reykjanes Ridge.

- To reconstruct BWT histories at Site 642. How large have these variations been? How far back in time can we reliably estimate BWT histories?

- To isolate perturbations in the subsurface temperature profile resulting from variations in BWT histories. Are observed temperature perturbations to the 
background thermal field in fact due to variations in BWT?

\section{Proposed research}

To capture thermal transients associated with temporal variations in BWT, we envision a borehole observatory in a new $\sim 180 \mathrm{~m}$ hole close to Site 642 , consisting of a CORK to seal the borehole from the overlying ocean, and a thermistor string and data logger to make and record the temperature measurements was envisioned. This configuration allows high-precision temperature measurements as a function of both depth and time. High-precision temperature measurements will be made at two timescales; in quick succession and over longer time intervals. Averaging a quick succession of temperature measurements is an effective way to reduce instrumental and environmental noise. Temperature measurements with an appropriate length of time between them can be used to directly monitor the propagation of transient temperatures (Chapman and Harris, 1992).

\section{Operations strategy}

At $67^{\circ} 12.7^{\prime} \mathrm{N}, 02^{\circ} 56.2^{\prime} \mathrm{E}$ (water depth $=1289 \mathrm{~m}$ ) near Hole $642 \mathrm{E}$, operations began by drilling to $\sim 180$ meters below seafloor (mbsf) with 103/4 inch casing and reentry cone. The bottom of the cased hole was sealed with cement to ensure against formation fluids entering the borehole interval where the measurements are made, and then the CORK and thermistor string were installed.

The operational plan for the new hole at Site 642 precluded a logging program in that hole. To assess current background thermal conditions in the region, however, a downhole record of temperature from Hole 642E was obtained, using the LamontDoherty Earth Observatory-Borehole Research Group (LDEO-BRG) high temperature tool. In addition to the temperature tool, the triple combination (triple combo) and the Formation MicroScanner (FMS)sonic tool strings were run in the northwest Atlantic between $\sim 30^{\circ}$ and $35^{\circ} \mathrm{N}$ (see "Downhole measurements" in the "Sites U1312-U1315 methods" chapter for description of tool strings).

\section{Principal results}

\section{Site U1312}

Site U1312 (proposed Site IRD-4A) constitutes a reoccupation of DSDP Site 608 located northeast of the Azores on the southern flank of the King's Trough tectonic complex in a water depth of $3554 \mathrm{~m}$ (Fig. F1). Two principal holes (Holes 608 and 608A) were drilled to 515.4 and 146.4 mbsf, respectively, with the variable-length hydraulic piston coring (VLHPC) system and the XCB system during Leg 94 (Ruddiman et al., 1987). At this site, a nearly continuous bio- and magnetostratigraphic section of Quaternary to middle-upper Oligocene sediments was recovered to 455 mbsf (Baldauf et al., 1987). Below this depth, some coring gaps and the presence of a major hiatus representing at least 7.5 m.y. (late Eocene-early Oligocene), cause the record to be less complete through the Oligocene and into the Eocene. Upper middle Eocene (NP16) sediments lie upon the basaltic basement at 515.4 mbsf. Mean sedimentation rates at Site 608 are $2-3 \mathrm{~cm} / \mathrm{k}$.y., with the higher values generally occurring in the late Neogene-Quaternary time intervals. Incomplete recovery and the present condition of the existing DSDP cores collected in 1983 do not permit the detailed paleoceanographic studies proposed here. The main objective at Site U1312 was to obtain continuous records of surface and deepwater characteristics and their interactions with ice sheet instabilities during NeogeneQuaternary times. In this context, an important target at this site was the recovery of a complete undisturbed upper Miocene section by means of APC.

Two holes were cored with the APC system and nonmagnetic core barrels at Site U1312. Hole U1312A was drilled to a maximum depth of 238.03 mbsf (Fig. F4), with a recovery of $104.5 \%$. In this hole, drillover was required for recovery of Cores $23 \mathrm{H}$ through $25 \mathrm{H}$. Because of excessive heave ( $>5 \mathrm{~m}$ ), initial coring conditions were not optimum. This prevented the recovery of a good mudline in Hole U1312A, and the first several cores $(1 \mathrm{H}$ through $3 \mathrm{H}$ and $5 \mathrm{H})$ were disturbed by flow-in. Hole U1312B was drilled to a maximum depth of 232.05 mbsf (Fig. F4), with a recovery of $102.1 \%$. In Hole U1312B, a successful mudline was achieved during a period of reduced heave, and drillover was required only for the recovery of Core $25 \mathrm{H}$. Drilling of a third hole was precluded as weather conditions dramatically deteriorated.

The Holocene to upper Miocene sedimentary succession at Site U1312 consists of varying mixtures of biogenic and detrital components, primarily nannofossils, foraminifers, and clay minerals. Based on sediment color, carbonate content, reflectance values, and the occurrence of detrital components, two lithostratigraphic units were distinguished. Unit I (0-78.95 mbsf in Hole U1312A; 0-79.70 mbsf in Hole U1312B; Holocene to late Pliocene) is dominated by nannofossil-rich sediments with varying amounts of foraminifers and terrigenous material. Alternating diffuse color bands occur throughout 
much of the unit. Most contacts between the various lithologies are gradational and/or bioturbated. Unit I was further divided into two subunits. Subunit IA exhibits high-amplitude variations in magnetic susceptibility and carbonate content, whereas in Subunit IB these variations are less distinct. Dropstones are generally rare and small (2-15 $\mathrm{mm}$ in diameter) and are concentrated in the upper $23 \mathrm{~m}$ of Subunit IA. Unit II (78.95-238.03 mbsf in Hole U1312A; 79.70-232.05 mbsf in Hole U1312B; late Pliocene to late Miocene) is dominated by nannofossil ooze that exhibits little change in color due to a downhole decrease in abundance of both detrital content and diffuse color bands.

Abundant, generally well preserved calcareous nannofossils and planktonic foraminifers occur throughout both holes at Site U1312. Planktonic foraminifer assemblages are mainly composed of species that thrive today or are related to temperate to subpolar waters, with some sporadic incursions of polar water and subtropical species. Nannofossil assemblages consist of cosmopolitan species typical of the North Atlantic at midlatitude. A reliable chronostratigraphic framework spanning from the late Miocene $(\sim 11 \mathrm{Ma})$ to the present was established based on the succession of biostratigraphic events identified in the cores (Table T1). Linear sedimentation rates were estimated based on the depth of these events. Average sedimentation rates were low during the late Miocene (1-2 cm/k.y.), increased in the early Pliocene (2.5-6 cm/k.y.), and decreased again in the latest Pliocene and Pleistocene (1.5-2 cm/k.y.) (Fig. F5). Although calcareous plankton species were usually well preserved, intense fragmentation of planktonic foraminifer shells and overgrown discoasters was observed in the uppermost Miocene (161-171 mbsf in Hole U1312A and 165-175 mbsf in Hole U1312B), coinciding with an interval of very low sedimentation rates. The occurrence of a hiatus due to carbonate dissolution in this part of the record is probable, since several biostratigraphic events were observed in the same core. A similar interval with extremely low sedimentation rates and/or a possible hiatus but good carbonate preservation was also observed in the upper Pliocene-lower Pleistocene (3847 mbsf in Hole U1312A and 32-41 mbsf in Hole U1312B). Nannofossils recovered from this interval in Hole U1312B indicate an age older than planktonic foraminifers from the same horizon, further suggesting the presence of a hiatus or significant reworking.

Biostratigraphy based on siliceous fossils was hindered by rare occurrences and dissolution of radiolarians and diatoms. Trace numbers of diatoms are present in the upper $\sim 60 \mathrm{~m}$ of both holes and show an age-depth progression similar to the calcareous nannofossils. Below $60 \mathrm{mbsf}$, the sediments are almost entirely barren of diatoms. Likewise, radiolarians are found in trace numbers to a depth of 85.5 mbsf in Hole U1312A and 114 mbsf in Hole U1312B. Only one radiolarian event was observed in Hole U1312B, whereas only samples at 28.5 and $37.5 \mathrm{mbsf}$ contained rich radiolarian faunas.

The magnetic interpretations at Site U1312 were based on measurements of the natural remanent magnetization (NRM) after alternating-field (AF) demagnetization at a peak field of $20 \mathrm{mT}$. The Brunhes/Matuyama reversal occurs at 18.40 mbsf in Hole U1312A and at 16.95 mbsf in Hole U1312B. The Jaramillo Subchron occurs between 20.90 and 24.80 mbsf in Hole U1312B. In Hole U1312B, the Gauss/ Matuyama and Gauss/Gilbert boundaries were tentatively placed at 51.60 and 72.2 mbsf, respectively, although a significant part of the Gauss interval (Chron C2An) is missing due to coring-induced sediment deformation. NRM intensities fall in the range of $10^{-5} \mathrm{~A} / \mathrm{m}$ between $\sim 100$ and $210 \mathrm{mbsf}$ in both holes. This range is close enough to the noise level of the magnetometer that establishing a continuous magnetostratigraphy was not possible by shipboard measurements. A long interval of normal polarity at the bottom of Holes U1312A and U1312B (top at 207.6 and $204.7 \mathrm{mbsf}$, respectively) was tentatively identified as Chron 5n (Fig. F6).

Because only two holes were cored and much of the upper portion of Hole U1312A was affected by coring disturbance, it was difficult to construct a complete splice for the entire sedimentary section. The remanent magnetic intensity following $20 \mathrm{mT}$ AF demagnetization and the lightness parameter from color reflectance measurements proved to be the most useful for correlating between holes to 158.89 mcd (the bottom of Core 307-U1312B-16H). Below $158.89 \mathrm{mcd}$, stratigraphic correlation was difficult because of the very uniform sediment composition, resulting in few diagnostic variations in physical properties. From 158.89 to 68.05 mcd, between-hole correlation was good and all core breaks could be filled, resulting in a complete splice. Above this, several gaps occur between core breaks, and much of the spliced section is built from Hole U1312B cores, which contained virtually no coring deformation within this interval. From 0 to $40 \mathrm{mcd}$, lightness $\left(\mathrm{L}^{*}\right)$ variations, which mainly reflect the carbonate content, mirror variations observed in the $0-1.5$ Ma portion of benthic oxygen isotope stacks. Sedimentation rates derived from this correlation vary between 0.5 and $3.5 \mathrm{~cm} / \mathrm{k} . \mathrm{y}$. over the past $1.5 \mathrm{Ma}$.

Alkalinity of the pore water in the upper $110 \mathrm{~m} \mathrm{ex}$ hibits a continuous trend in increasing values down- 
hole to a depth of $\sim 80 \mathrm{mbsf}$, followed by a decrease thereafter. In contrast, chlorinity decreases with depth. The highest silica value of $\sim 641 \mu \mathrm{M}$ was measured at 53.5 mbsf. Barium exhibits its highest values $(0.7 \mu \mathrm{M})$ at $82 \mathrm{mbsf}$, just below the boundary between lithostratigraphic Units I and II.

Carbonate concentration in the sedimentary record of Hole U1312A ranges from 59 to $98 \mathrm{wt} \%$ (average = $90.4 \mathrm{wt} \%)$. Highest values (92-98 wt\%) are observed in the lower part of the record (below $~ 55 \mathrm{mbsf}$ ), whereas the top $\sim 55 \mathrm{~m}$ (lithostratigraphic Subunit IA) is characterized by lower values and high variability. Two discrete intervals of decreased $\mathrm{CaCO}_{3}$ values (82 wt\%) occurred at 81.95 and $110.45 \mathrm{mbsf}$. A similar trend was observed in the overall $\mathrm{CaCO}_{3}$ concentration at Site 608. Total organic carbon varies between 0 and $0.9 \mathrm{wt} \%$, with the lowest values $(0$ $0.1 \mathrm{wt} \%$ ) found below $85 \mathrm{mbsf}$ and higher and more variable values (0.1-0.9 wt\%) above. Total nitrogen is low and relatively constant throughout the hole $(\sim 0.1 \mathrm{wt} \%)$.

Physical property measurements at Site U1312 included magnetic susceptibility, density, and natural gamma radiation (Fig. F7). Working sections were used to measure moisture and density (MAD) and compressional $P$-wave velocity. These properties generally show greatest variability in the upper $40 \mathrm{~m}$ consistent with greater clay content and generally show lower values with depth, except for density and $P$-wave velocity, which increase with depth.

Site U1312 accomplished near full recovery of the excellent upper Miocene section first drilled at Site 608 . The sedimentary sequence representing the last $\sim 11$ m.y. will allow for the study of short- and longterm climate variability and ocean-atmosphere interactions under very different boundary conditions, such as the closure and reopening of Atlantic/Mediterranean connections at the end of the Miocene (6$5 \mathrm{Ma}$ ), the closing of the Isthmus of Panama (4.5-3 $\mathrm{Ma})$, and the onset of major northern hemisphere glaciation near 2.5 Ma.

\section{Site U1313}

Site U1313 (proposed Site IRD-3A) constitutes a reoccupation of DSDP Site 607 located at the base of the upper western flank of the Mid-Atlantic Ridge in a water depth of $3426 \mathrm{~m}, \sim 240 \mathrm{mi}$ northwest of the Azores. Two holes were drilled at this site during Leg 94 (June-August 1983) using VLHPC and XCB systems (Ruddiman et al., 1987). Hole 607 penetrated to a total depth of $284.4 \mathrm{mbsf}$ and Hole 607A to a total depth of 311.3 mbsf. The sediments recovered at Site 607 predominantly consist of calcareous biogenic oozes with variable amounts of fine-grained terrige- nous material. Based on magneto- and biostratigraphy, the mean sedimentation rate at Site 607 is $\sim 5$ $\mathrm{cm} / \mathrm{k}$.y. for the Pliocene-Pleistocene time interval.

The rationale for reoccupying this site is essentially the same as for Site U1308 (recoring of Site 609; see "Expedition 303 summary"). Together, Sites 607 and 609 constitute benchmark sites for long-term (millions of years) as well as short-term surface and deep ocean climate records from the subpolar North Atlantic. These sites, today situated under the influence of the NADW, have been very important for generating benthic $\delta^{18} \mathrm{O}, \delta^{13} \mathrm{C}$, and $\mathrm{CaCO}_{3}$ records for the Pleistocene (Ruddiman et al., 1989; Raymo et al., 2004) and late Pliocene (Ruddiman et al., 1986; Raymo et al., 1989) and for interpreting these records in terms of ice sheet variability and changes in NADW circulation, as well as for generating orbitally tuned timescales. Site 607, at a water depth of $3427 \mathrm{~m}$, remains the only site in the high-latitude North Atlantic that monitors NADW circulation throughout the Pleistocene.

Reconstruction of sea-surface temperatures (SST) in the North Atlantic indicates that the Polar Front was situated between $42^{\circ}$ and $46^{\circ} \mathrm{N}$ during glacial times, extending in an east-west direction and resulting in a steep south-north SST gradient (CLIMAP, 1976; Pflaumann et al., 2003). Alkenone SST estimates determined in sediment cores from areas south of and within the Polar Front resulted in very different values for different glacials (Calvo et al., 2001), indicating different climatic conditions (e.g., the location of the Polar Front) in these glacial periods. At the site of Core VM 30-97, located close to Site 607, Heinrich events are marked by the distinctive detrital carbonate signature, and planktonic foraminifer-derived SST warmed markedly during the Heinrich events and during the Last Glacial Maximum (LGM), in distinct contrast to the climate records from the subpolar North Atlantic (Bond et al., 1999a).

Four holes (U1313A, U1313B, U1313C, and U1313D) were cored with the APC system and nonmagnetic core barrels to a maximum depth of 308.64, 302.67, 293.45, and 152.34 mbsf, respectively (Fig. F8). The average recovery was $103.5 \%$. In Holes U1313A and $\mathrm{U} 1313 \mathrm{C}$, drillover was required for recovery of the last two and four cores, respectively. After completing coring operations in Hole U1313B, the hole was prepared for logging and the triple combo tool string was deployed (including the General Purpose Inclinometer Tool and Multi-Sensor Spectral Gamma Ray Tool) to $2.0 \mathrm{~m}$ off the bottom of the hole. The entire $300 \mathrm{~m}$ sequence was successfully logged.

The Holocene to uppermost Miocene sedimentary succession at Site U1313 consists primarily of nannofossil ooze with varying amounts of foraminifers and 
clay- to gravel-sized terrigenous components. Two major lithostratigraphic units were identified. Unit I (0-111.86 mbsf in Hole U1313A, 0-111.28 mbsf in Hole U1313B, 0-112.00 in Hole U1313C, and 0113.14 mbsf in Hole U1313D) mainly consists of Holocene to upper Pliocene alternating nannofossil ooze, silty clay nannofossil ooze, and nannofossil ooze with clay. Regular occurrences of dropstones in Unit I demonstrate that northern hemisphere ice sheet instability plays a role in the sediment's paleoclimate record from the late Pliocene to Pleistocene. Unit I can be further divided into two subunits. Subunit IA exhibits the largest amplitude fluctuations in detrital clay and biogenic carbonate and is reflected by distinct color changes and shifts in $\mathrm{L}^{*}$ (Fig. F8), percent carbonate, gamma ray attenuation, and magnetic susceptibility, whereas Subunit IB is defined by decreased variability in these components. Millimeter- to centimeter-scale pale green color bands are distributed throughout the succession, and a horizon of reworked volcanic ash can be correlated across all holes in Subunit IA. Unit II extends to the bottom of each hole (111.86-308.64 mbsf in Hole U1313A, 111.28-302.67 mbsf in Hole U1313B, 112.00-293.45 mbsf in Hole U1313C, and 113.14152.34 mbsf in Hole U1313D). Unit II is very homogeneous and differs from Unit I mainly in its smaller terrigenous component, which decreases gradually downhole from the unit boundary to $\sim 150 \mathrm{mbsf}$. Unit II consists of upper Pliocene to uppermost Miocene nannofossil ooze and is characterized by high and stable carbonate concentrations. Discrete patches and streaks of pyrite occur throughout this unit and are probably related to local reducing conditions associated with organic matter complexes. Pale green color bands continue to be prevalent in the otherwise nearly white sediment.

Site U1313 yielded abundant assemblages of calcareous microfossils spanning the late Miocene to Holocene. Biostratigraphic events based on calcareous microfossils closely match ages based on paleomagnetic data for the Pliocene and Pleistocene and indicate nearly constant sedimentation rates of $4-5 \mathrm{~cm} /$ k.y. throughout this time interval (Fig. F5). The oldest sediments at Site U1313 are tentatively dated at 6 Ma based on a nannofossil last occurrence near the base of Holes U1313A and U1313C, a tentative planktonic foraminifer event at the base of Hole U1313A, and a possible diatom event in Core 307U1313C-32H (Table T1). Based on these biostratigraphic events, sedimentation rates within the late Miocene are $13-14 \mathrm{~cm} /$ k.y. (Fig. F5).

Calcareous nannofossils are well preserved throughout much of the section, although some dissolution and overgrowth is present within the upper Mio- cene. Pleistocene sediments contain very minor amounts of reworked nannofossils. Planktonic foraminifers are moderately to well preserved and reveal a high faunal diversity including several (sub)tropical species. An incursion of encrusted Neogloboquadrina atlantica (dextral) occurs in the lower Pleistocene, making this the youngest occurrence of this species in the midlatitude North Atlantic.

A diverse warm-water diatom flora is generally present within the upper 0 to $40-70$ mbsf of each hole, which corresponds to Pliocene-Pleistocene intervals. These sediments contain an in-mix of Arctic and Subarctic, possibly ice-rafted species. Diatoms, however, are only abundant in the first two core catchers and occur only as traces below 50-60 mbsf. When present, warm-water diatoms are generally well preserved but often fragmented. The diatoms from colder water masses are usually partially dissolved.

Radiolarians reveal great variation in abundance, state of preservation, and faunal associations among the four holes. Generally, radiolarians are abundant and well preserved in the upper five to six core catcher samples of each hole, whereas dissolution is severe in the lower part. Cycladophora davisiana is found in samples as many as 14 cores deeper than its anticipated first occurrence (at 2.6 Ma) in the North Atlantic. If these occurrences are real and not a result of downhole contamination, then the first occurrence of $C$. davisiana is $\sim 5.5 \mathrm{Ma}$.

The magnetostratigraphy at Site U1313 was constructed on the basis of continuous NRM measurements after AF demagnetization at a peak field of 20 $\mathrm{mT}$. NRM intensities after $20 \mathrm{mT}$ AF demagnetization are in the range of $10^{-3}$ to $10^{-4} \mathrm{~A} / \mathrm{m}$ above $150 \mathrm{mbsf}$, but fall in the range of $10^{-5} \mathrm{~A} / \mathrm{m}$ in the lower part of the section. The sediments provide a good record of the Brunhes, Matuyama, and Gauss polarity intervals down to $\sim 150$ mbsf (Fig. F6). Below this depth, the inclination signal is noisier but alternating intervals of normal and reversed polarities can still be defined with confidence to $\sim 250$ mbsf. The magnetostratigraphy is uncertain below this depth, as it varies from one hole to the other, part of which might be due to the stronger drill string overprint induced by alloy steel core barrels used in the bottom part of Holes U1313A and U1313C instead of nonmagnetic core barrels. The magnetostratigraphy is consistent with the biostratigraphy from the top to 220 mbsf. In the underlying sediment, however, the link to the biostratigraphy is not straightforward (Fig. F5).

The four holes cored at Site U1313 provided ample sediment for constructing one complete spliced stratigraphic section and a second nearly complete section. Correlation between holes was excellent in the 
upper 168.5 mcd because of pronounced variations in nearly all physical properties measured. In particular, the $L^{*}$ parameters from color reflectance measurements mimic variations in the global benthic oxygen isotope stack (e.g., Lisiecki and Raymo, 2005), and a preliminary age model was constructed by matching sharp $L^{*}$ variations with glacial and interglacial terminations. Between-hole correlation was more difficult below 168.5 mcd ( 151 mbsf), because the sediments are fairly homogeneous nannofossil ooze.

Apart from their general trends, most pore water chemical constituents show a notable change between $\sim 80$ and 110 mbsf (i.e., at the transition between lithostratigraphic Units I and II). Alkalinity and $\mathrm{Sr}^{2+}$ increase downhole, while $\mathrm{Li}^{+}$decreases. The highest dissolved silica content of $\sim 563 \mu \mathrm{M}$ is measured at 39.3 mbsf. $\mathrm{SO}_{4}{ }^{2-}$ concentration exhibits a slight downhole decrease from $\sim 26$ to $24 \mu \mathrm{M}$, whereas the $\mathrm{NH}_{4}{ }^{+}$shows an opposite trend (126-418 $\mu \mathrm{M}$ with a high value of $615 \mu \mathrm{M}$ at $47.8 \mathrm{mbsf})$. $\mathrm{Ba}^{2+}$ shows a more or less uniform concentration $(\sim 3.2$ $\mu \mathrm{M})$ throughout the profile.

Carbonate concentrations in the sediments of Hole U1313A range from 31.5 to $96.7 \mathrm{wt} \%$ (average $=80.5$ $\mathrm{wt} \%$ ). Relatively uniform and high values (>90 wt\%) are observed below $\sim 120$ mbsf (Unit II), whereas the top $\sim 120$ mbsf (Unit I) is characterized by distinct and strong variations (30-90 wt\%). Maximum amplitude with up to $60 \mathrm{wt} \%$ difference in $\mathrm{CaCO}_{3}$ occurs in the uppermost $40 \mathrm{mbsf}$, whereas the amplitude of variation is reduced to $40-50 \mathrm{wt} \%$ from 40 to 120 mbsf. Similar general features of the $\mathrm{CaCO}_{3}$ variability were observed at Site 607 . Total organic carbon varies between 0 and $0.65 \mathrm{wt} \%$, with the lowest values $(<0.1 \mathrm{wt} \%)$ below $170 \mathrm{mbsf}$ but higher and more variable values (0.1-0.65 wt \%) above. Total nitrogen is low and relatively constant throughout the hole $(0.1-0.15 \mathrm{wt} \%)$. Preliminary results from a limited number of samples (16) show that solvent extractable organic matter at Site U1313 consists primarily of odd-numbered $\mathrm{C}_{25}-\mathrm{C}_{35} n$-alkanes and long chain $\mathrm{C}_{37}-\mathrm{C}_{40}$ alkenones. Variations in proportions of these compound classes reflect a change in the organic matter composition with respect to terrigenous and marine sources. Alkenone-derived SSTs show variability from $\sim 13^{\circ}$ to $19^{\circ} \mathrm{C}$ in the Pleistocene, whereas temperatures of $\sim 20^{\circ}$ and $22^{\circ} \mathrm{C}$ are obtained for the late Pliocene and the latest Miocene, respectively.

Physical properties measured at Site U1313 include magnetic susceptibility (by multisensor track [MST] and magnetic susceptibility core logger), gamma ray attenuation (GRA) density, $P$-wave logger, and natural gamma radiation (NGR) using the MST. In addition, porosity and density were measured on discrete samples by MAD. Finally, $P$-wave velocities were measured in the $\mathrm{x}$-direction using the $P$-wave sensor. The results show a large variability of all physical properties in the upper $\sim 120-140 \mathrm{~m}$, which is probably related to the variation of clay content in the upper part (Fig. F8). Below 120 mbsf, the variability in physical properties is small as a result of the very high carbonate content (>95 wt\%).

The successful deployment of the triple combo tool string in Hole U1313B provided complete coverage of the $300 \mathrm{~m}$ section and very good physical property and lithologic information for density, porosity, natural gamma radiation, resistivity, and photoelectric effect. Corresponding core physical property measurements were very consistent with in situ downhole data. Of special note is the dramatically consistent linear correlation of downhole NGR (upper 225 mbsf) with the recent Lisiecki and Raymo (2005) benthic oxygen isotope record over the last 5.3 m.y. The consistency of downhole data with both core data and age models will allow mapping of the spliced core record to actual depth, resulting in more accurate sedimentation rate calculations as well as more detailed age/depth models.

Site U1313 (especially in combination with similar records from other Expedition 303 and 306 sites) will document the evolution of the complex surfacetemperature phasing over time, addressing questions such as whether the patterns are a peculiarity of the last glaciation, whether they were present in the 41k.y. world, and whether they appeared at the onset of northern hemisphere glaciation. By placing the surface-temperature signals into a chronological framework based on a combination of oxygen isotopic stratigraphy, detrital carbonate-bearing IRD (Heinrich-type) events, and geomagnetic paleointensity, we expect to obtain an optimal reconstruction of the phasing of the temperature records and its relationship to ice sheet instability and changes in deepwater circulation.

\section{Site U1314}

Site U1314 (proposed Site GAR1B) is located on the southern Gardar Drift in a water depth of $2800 \mathrm{~m}$ (Fig. F1). Close to the location of Site U1314, a $33 \mathrm{~m}$ Marion Dufresne core (MD99-2253) was collected on the crest of the Gardar Drift in 1999 (Labeyrie et al., 2003). The MD99-2253 piston core has a high sedimentation rate of $\sim 9 \mathrm{~cm} / \mathrm{k} . \mathrm{y}$. for the last glacial cycle and well-defined planktonic $\delta^{18} \mathrm{O}$ and geomagnetic paleointensity record reference. During Leg 162, Sites 983 and 984 were drilled off Iceland on the northern part of the Gardar and Bjørn Drifts, respectively (Fig. F2). These sites have mean Pleistocene sedimentation rates in the $10-15 \mathrm{~cm} / \mathrm{k} . \mathrm{y}$. range and 
have produced high resolution climatic and geomagnetic records. Sites 983 and 984, however, are located outside the main IRD belt (Fig. F2) and do not contain a robust detrital carbonate (Heinrich layer) signal. Furthermore, both sites are at shallower water depths $(<2000 \mathrm{~m})$ than Site U1314 and therefore monitor intermediate water but not NADW. Site U1314, on the other hand, is located (1) close enough to the IRD belt to record the Heinrich-type detrital layers that monitor ice sheet instability and (2) in a water depth of $2820 \mathrm{~m}$, allowing for a highresolution monitoring of NADW and its short-term (sub)millennial scale variability.

Three holes (Holes U1314A, U1314B, and U1314C) were cored with the APC system and nonmagnetic core barrels to maximum depths of 257.58, 279.91 and 208.18 mbsf, respectively (Fig. F9). The average recovery was $102.7 \%$. Drillover was not required for the three holes.

The sedimentary sequence at Site U1314 mainly consists of nannofossil- and clay-rich sediments with minor and varying proportions of diatoms and foraminifers. Only one lithostratigraphic unit was defined at Site U1314, which spans the late Pliocene to Holocene time interval. In particular, two sets of lithologies can be identified:

1. Predominantly nannofossil oozes enriched in biogenic (mainly diatoms and foraminifers) and terrigenous (principally clay minerals, quartz, opaque minerals, and calcite) components; and

2. Terrigenous silty clay with a varying proportion of calcareous and siliceous microfossils.

The sediment varies in color from very dark gray to light gray to hues of greenish gray. Slight to moderate bioturbation is typical for most of the section. Horizontal and parallel bedding planes and color contacts without erosional relief suggest that there is no visible evidence of significant sediment disturbance by natural processes. Sand- and gravel-sized sediment, common at Site U1314 from 0 to 240 mbsf, provides direct evidence of ice rafting and documents the influence of Pliocene-Pleistocene glaciations in this region. Based on the occurrence of felsic and mafic igneous dropstones, as well as sand-sized, hematite-stained quartz, Iceland and Greenland are probable source areas of the IRD material.

Site U1314 yields abundant assemblages of calcareous and siliceous microfossils spanning the late Pliocene to Holocene (Table T1). Sedimentation rates based on microfossil datums and paleomagnetism indicate decreasing rates from $\sim 11-11.5 \mathrm{~cm} / \mathrm{k} . \mathrm{y}$. during the late Pliocene to $\sim 7.0-7.5 \mathrm{~cm} / \mathrm{k}$.y. during the Pleistocene (Fig. F5). Polar and subpolar species dominate the assemblages with a subordinate amount of transitional species present as well.
Calcareous nannofossils are abundant and generally well preserved throughout the section. Minor amounts of Cretaceous and Paleogene reworked nannofossils occur in all holes. Samples with increased amounts of reworked material typically contain coarser sediment and reduced abundances of in situ nannofossils. Late Pliocene discoasters are rare, but present, and can be used with caution for biostratigraphy, even though they are considered warm-water species. Generally well preserved planktonic foraminifers are the dominant component in the sand fraction of most core catcher samples, with lower proportions of benthic foraminifers, ostracodes, siliceous microfossils, and IRD. Fauna consists of species typical for transitional to subpolar provinces in the Pleistocene and Pliocene. Neogloboquadrina pachyderma (sinistral) is dominant in several of the glacial samples.

Abundant and diverse boreal to Subarctic diatom floras, with a minor input of warm-water species, are present in all holes. The exception is the interval between 307-U1314A-13H-CC and 15H-CC, where few or rare diatoms coincide with high content of siliciclastic material. The preservation is generally moderate to good, with a deteriorating trend downhole, as well as poor preservation coinciding with lithic-rich intervals. The flora is dominated by long pennate specimens, as well as resting spores of Chaetoceros and fragments of big Coscinodiscus species.

Radiolarians at this site show great variation in species and abundances among the three holes. The state of preservation is generally good in all holes. $C$. davisiana is found in most samples, with a first common occurrence in Samples 307-U1314A-25H-CC and 307-U1314B-24H-CC. This species has a first common abundance in the North Atlantic at 2.6 Ma. Cycladophora sakaii is commonly found in Samples 25H-CC in Holes U1314A and U1314B. In the North Pacific, C. sakaii evolves into C. davisiana at $\sim 2.6 \mathrm{Ma}$. This is the first documented occurrence of C. sakaii in the North Atlantic. The last occurrence of Spongaster ?tetras $(2.6 \mathrm{Ma})$ is found in Samples 307U1314A-28H-CC and 307-U1314B-27H-CC.

The magnetostratigraphy at Site U1314 was constructed on the basis of continuous NRM measurements after AF demagnetization at a peak field of 20 mT. NRM intensities after $20 \mathrm{mT}$ AF demagnetization are in the range of $10^{-1}$ to $10^{-2} \mathrm{~A} / \mathrm{m}$. These values are considerably greater than those at Sites U1312 and U1313, owing to a higher magnetic mineral content. Site U1314 provides a very good record of the Brunhes, Matuyama, and upper part of the Gauss Chrons (Fig. F6). The Brunhes/Matuyama reversal occurs at $57.3 \pm 0.1 \mathrm{mbsf}$ in Hole U1314A, $56.6 \pm 0.1 \mathrm{mbsf}$ in Hole U1314B, and $57.7 \pm 0.1$ mbsf in Hole U1314C. 
The deepest magnetic polarity interval recorded at Site U1314 corresponds to the top normal interval of the Gauss (Subchron 2An.1n; $2.58 \mathrm{Ma}$ ). Several short geomagnetic intervals are present in the paleomagnetic record, such as the Cobb Mountain and the Reunion events. The magnetostratigraphy is consistent with the biostratigraphy throughout the section.

Stratigraphic correlation was straightforward at Site U1314 because most of the sediment physical properties show prominent short-wavelength amplitude variations related to changes in lithology. For depthshifting the cores, we relied mainly on between-hole correlation of distinctive magnetic susceptibility and natural gamma ray variations. These correlations were confirmed to be consistent with geomagnetic polarity reversals recorded in the paleomagnetic inclination. The resulting mcd scale is well resolved, and the spliced section is complete to $281 \mathrm{mcd}$. Because of core disturbance in the upper part of Hole U1314A, the splice in the interval $0-188.30$ mcd was built from Holes U1314B and U1314C, with the exception of a short interval (65.80-69.50 mcd) where an undisturbed section of Core $307-\mathrm{U} 1314 \mathrm{~A}-8 \mathrm{H}$ was incorporated into the composite section. From 188.30 to 300 mcd the splice was constructed from Holes U1314A and U1314B because Hole U1314C was drilled only to $222 \mathrm{mcd}$. The two deepest cores, 307-U1314B-29H and 30H, which span an interval not cored in Holes U1314A or U1314C, were appended to the splice. A growth factor of 1.08 is calculated by linear regression for the three holes at Site U1314, indicating an 8\% increase in mcd relative to mbsf.

The ionic composition of the pore waters at Site U1314 was measured between Cores 307-U1314A-1H and $12 \mathrm{H}$. Pore water alkalinity increases downhole from 5.34 to $7.46 \mathrm{mM}$. $\mathrm{Ca}^{2+}$ and $\mathrm{Mg}^{2+}$ concentrations decrease downhole from 8.4 to $5.2 \mathrm{mM}$ and 48.7 to $37.4 \mathrm{mM}$, respectively. $\mathrm{Fe}^{2+}$ concentrations are variable, with the lowest value $(6.5 \mu \mathrm{M})$ measured at 36.4 mbsf, which coincides with more abundant darker lithologies. $\mathrm{Ba}^{2+}$ concentration is higher at Site U1314 than at the other sites, ranging from 17 to $18.3 \mu \mathrm{M} . \mathrm{Mn}^{2+}$ concentration ranges from 46.8 to $15.9 \mu \mathrm{M}$ and shows a rapid decrease downhole between 17.4 and 36 mbsf. $\mathrm{H}_{4} \mathrm{SiO}_{4}$ concentration increases with depth from 487.6 to $571.9 \mu \mathrm{M}$.

Carbonate concentrations in the sediments of Hole U1314A range from 3.7 to $70.5 \mathrm{wt} \%$. The average carbonate value linearly shifts from $20 \mathrm{wt} \%$ at 250 mbsf toward $40 \mathrm{wt} \%$ near the top. $\mathrm{CaCO}_{3}$ values show a good correlation to $\mathrm{L}^{*}$ data throughout the section. Total organic carbon (TOC) varies between $<0.1$ and $0.5 \mathrm{wt} \%$ with an average of $0.2 \mathrm{wt} \%$. The downhole TOC variation is similar to the variability in magnetic susceptibility, suggesting that organic carbon at Site U1314 is primarily of terrigenous origin. Based on initial results from eight samples, solvent extractable organic matter at Site U1314 consists mainly of long-chain, odd-numbered $\mathrm{C}_{25}-\mathrm{C}_{35} n$ alkanes and long-chain $\mathrm{C}_{37}-\mathrm{C}_{40}$ alkenones. Except for one sample from the upper Pliocene, all Pleistocene samples show a distinct prevalence of $n$-alkanes relative to alkenones, confirming the assumption of a mainly terrigenous origin of the organic matter at Site U1314. Alkenone-derived SSTs vary between $\sim 10^{\circ}$ and $13^{\circ} \mathrm{C}$.

Physical property measurements at Site U1314 included magnetic susceptibility, density, $P$-wave velocity, and NGR (Fig. F9). Working sections were used to measure MAD and compressional $P$-wave velocity. These properties are positively correlated, consistent with the terrigenous nature of the sediment. The magnetic susceptibility records, for example, show a highly variable record attributed to lithologic and/or mineralogic changes; multiple excursions toward high values are generally associated with IRD layers.

At Site U1314, a complete upper Pliocene to Holocene sequence, characterized by high sedimentation rates of 7 to $>11 \mathrm{~cm} / \mathrm{k}$.y., was recovered. Because of its location close to the IRD belt and within the NADW, as well as its high potential for paleomagnetic and isotopic age control, this section will be used to establish a high-resolution (millennial to submillennial) environmental record of sea-surface and bottom water characteristics and a detrital (Heinrich type) stratigraphy for the past 2.7 m.y.

\section{Site U1315}

Site 642 (Site U1315), located on the Vøring Plateau in a water depth of $\sim 1280 \mathrm{~m}$, was visited during Leg 104 (Eldholm, Thiede, Taylor, et al., 1987) (see Fig. F1 in the "Site U1315" chapter). In Hole 642E, a $1229 \mathrm{~m}$ deep sequence was drilled that is composed of upper Eocene to Quaternary biogenic and terrigenous sediments with volcaniclastics in the lower part (lithostratigraphic Units I-IV; 0-315 mbsf) and Eocene tholeiitic (upper series) and andesitic (lower series) basalt flows with interbedded volcaniclastic sediments (315-1229 mbsf) (see Fig. F2 in the "Site U1315" chapter). The location of Site 642 was revisited during Expedition 306 (Site U1315A; $67^{\circ} 12.74^{\prime} \mathrm{N}, 02^{\circ} 56.24^{\prime} \mathrm{E}$ ).

The primary objective at this site is to document BWT variations and monitor its subbottom diffusion over a 5 y period. BWT and salinity variations are monitored with instrumentation that sits in the water column via an elevated reentry cone. Diffusion of 
the thermal wave through the subsurface is monitored with a $150 \mathrm{~m}$ thermistor string deployed in a cased borehole fitted with a CORK. Hole U1315A was drilled to a depth of 179.07 mbsf and cased with $10^{3 / 4}$ inch casing. The base of the casing was cemented and the casing string was displaced with bentonite mud. The thermistor string is attached to Spectra rope using friction tape, cable ties, and marine duct tape to carry the weight of the load and a $250 \mathrm{lb}$ sinker bar. The thermistor string is connected to a data logger and external battery.

To assess current background thermal conditions in the region, a downhole record of temperature from nearby Hole 642E was obtained using the LDEO Temperature/Acceleration/Pressure (TAP) tool in combination with the triple combo tool string. In addition, the FMS-sonic tool was deployed. At a depth of 588 mbsf, an impassable obstruction was reached, and downhole logging had to be stopped. The TAP tool indicated a BWT at the seafloor of $\sim 0.2^{\circ} \mathrm{C}$. The upper $10 \mathrm{~m}$ of the borehole has a very steep thermal gradient $\left(\sim 2500^{\circ} \mathrm{C} / \mathrm{km}\right)$. Below this depth, the borehole has a relatively low gradient of $\sim 22^{\circ} \mathrm{C} / \mathrm{km}$. At a depth of $\sim 500 \mathrm{mbsf}$, a strong positive temperature excursion to $\sim 42^{\circ} \mathrm{C}$ may indicate inflow. FMS imaging of the hole yielded good results and will allow correlation to existing core data and filling in the gaps ( $\sim 60 \%$ of the formation). In combination with detailed FMS resistivity measurements and imaging and sonic data, it may be possible to get reliable permeability estimates. Understanding the permeability will allow better understanding of fluid flow and temperature gradients observed in the borehole.

\section{Summary and conclusions}

Following Expedition 303, Expedition 306 was the second cruise of the North Atlantic paleoceanography study that aims to generate a late NeogeneQuaternary chronostratigraphic template for North Atlantic climate proxies, to allow their correlation at a sub-Milankovitch scale and their export to other parts of the globe by using a PAC. In addition, Expedition 306 also included the installation of a CORK near Site 642 (Vøring Plateau, Norwegian margin) to investigate the feasibility of reconstructing BWT histories at the decadal to centennial timescale by making high-precision temperature-depth measurements.

Based on the Expeditions 303 and 306 Scientific Prospectus and results of Expedition 303, Sites IRD3A and IRD4A and two sites on Eirik Drift were originally selected to become the primary Expedition 306 sites. Extremely bad weather conditions in the Labra- dor Sea, however, did not allow coring operations on Eirik Drift at any time. Thus, we concentrated our work related to the North Atlantic paleoceanography study in the area directly south of the central North Atlantic IRD belt and on the southern Gardar Drift. These locations are known either from Leg 94 or from conventional piston coring to have the potential for paleomagnetic and isotopic age control and sedimentation rates high enough for high-resolution reconstructions of sea-surface and bottom water characteristics and ice sheet instabilities during late Neogene to Pleistocene times.

The main objective at Site U1312, a reoccupation of Site 608, was to obtain continuous records of surface and deepwater characteristics and their interactions with ice sheet instabilities during Neogene-Quaternary times. In this context, an important target at this site was the recovery of a complete undisturbed upper Miocene section by means of APC coring. The Holocene to upper Miocene sedimentary succession at Site U1312 consists of varying mixtures of biogenic and detrital components, primarily nannofossils, foraminifers, and clay minerals. Near $3.5 \mathrm{Ma}$, the progressive but oscillatory deterioration of the northern hemisphere climate, which gradually led to the onset of major continental ice sheets at $\sim 2.7 \mathrm{Ma}$, is reflected in the increase in detrital sediment input, followed by late Pliocene-Pleistocene climate-controlled short-term variability in detrital input. Average sedimentation rates were low during the late Miocene and in the latest Pliocene and Pleistocene $(1-2 \mathrm{~cm} / \mathrm{k} . \mathrm{y}$.) but increased in the early Pliocene (3-8 $\mathrm{cm} / \mathrm{k} . \mathrm{y}$.$) .$

The sedimentary sequence of Site U1312 representing the last $\sim 11 \mathrm{~m}$.y. will allow the study of shortand long-term climate variability and ocean-atmosphere interactions under very different boundary conditions, such as the closure and reopening of Atlantic/Mediterranean connections at the end of the Miocene (6-5 Ma), the closing of the Isthmus of Panama (4.5-3 Ma), and the onset of major northern hemisphere glaciation at $2.7 \mathrm{Ma}$.

Site U1313 is a reoccupation of Site 607. Site 607 has been very important for generating a late Pliocene to Pleistocene stable isotope stratigraphy and its interpretation in terms of ice sheet variability and changes in NADW circulation. At the site of Core VM 30-97, located close to Site 607, Heinrich events are marked by the distinctive detrital carbonate signature, and planktonic foraminifer-derived SSTs warmed markedly during the Heinrich events and during the LGM, in distinct contrast to the climate records from the subpolar North Atlantic.

At Site U1313, four holes with a maximum penetration to 308.6 mbsf were drilled. The Holocene to up- 
permost Miocene sedimentary succession at Site U1313 consists primarily of nannofossil ooze with varying amounts of foraminifers and clay- to gravelsized terrigenous components. The detrital components become much more important and variable in the upper Pliocene-Pleistocene interval of the sequence, probably reflecting northern hemisphere ice sheet instability. Bio- and magnetostratigraphy indicate nearly constant sedimentation rates of $\sim 4.1-4.5$ $\mathrm{cm} / \mathrm{k} . \mathrm{y}$. throughout the Pliocene-Pleistocene time interval, whereas in the late Messinian sedimentation rates were $\sim 13-14 \mathrm{~cm} / \mathrm{k} . y$. Correlation between the holes was excellent in the upper 168.5 mcd because of pronounced variations in nearly all physical properties measured. In particular, the $\mathrm{L}^{*}$ from color reflectance measurements mimic variations in the global benthic oxygen isotope stack (e.g., Lisiecki and Raymo, 2005), and a preliminary age model was constructed by matching sharp $L^{*}$ variations with glacial and interglacial terminations. Alkenonederived SSTs show variability from $\sim 13^{\circ}$ to $19^{\circ} \mathrm{C}$ in the Pleistocene, whereas temperatures of $\sim 20^{\circ}$ and $22^{\circ} \mathrm{C}$ are obtained for the late Pliocene and the latest Miocene, respectively. The consistency between downhole-logging data and core data will allow mapping of the spliced core record to actual depth, resulting in more accurate sedimentation rate calculations as well as more detailed age-depth models. Of special note is the very consistent linear correlation of downhole NGR (upper $225 \mathrm{mbsf}$ ) with the recent Lisiecki and Raymo (2005) benthic oxygen isotope record over the last $5.3 \mathrm{~m} . \mathrm{y}$.

Site U1313 provides a unique and complete Pliocene-Pleistocene sedimentary section with remarkably constant sedimentation rates. This site will allow an optimal reconstruction of the phasing of the temperature records and its relationship to ice sheet instability and changes in deepwater circulation throughout the last $5 \mathrm{~m} . \mathrm{y}$. High sedimentation rates of $13-14 \mathrm{~cm} / \mathrm{k} . \mathrm{y}$. will allow a high-resolution study of paleoenvironmental change during the late Messinian.

Site U1314 was drilled on the southern Gardar Drift, close enough to the IRD belt to record the Heinrichtype detrital layers that monitor ice sheet instability, and in water depth of $2800 \mathrm{~m}$, allowing a highresolution monitoring of NADW and its short-term (sub)millennial scale variability.

The upper Pliocene to Holocene sedimentary sequence at Site U1314 consists of an alternation of predominantly nannofossil oozes enriched in biogenic and terrigenous components and terrigenous silty clay with a varying proportions of calcareous and siliceous microfossils. This alternation is also reflected in the carbonate content, varying between $\sim 5$ and 70 wt $\%$. Sand- and gravel-sized sediment, common at Site U1314 from 0 to 240 mbsf, provides direct evidence of ice rafting and documents the influence of Pliocene-Pleistocene glaciations in this region. Site U1314 yields abundant moderately to well-preserved assemblages of calcareous and siliceous microfossils throughout the section and an excellent paleomagnetic record of the Brunhes, Matuyama, and the upper part of the Gauss Chrons. Even several short geomagnetic reversals are present in the paleomagnetic record. Sedimentation rates based on microfossil datums and paleomagnetic reversals indicate decreasing rates from $\sim 11-11.5 \mathrm{~cm} / \mathrm{k} . \mathrm{y}$. during the late Pliocene to $\sim 7.0-7.5 \mathrm{~cm} / \mathrm{k} . \mathrm{y}$. during the Pleistocene. Stratigraphic correlation was straightforward at Site U1314 because most of the sediment physical properties show prominent short-wavelength amplitude variations. The resulting mcd scale is well resolved, and the spliced section is complete to 281 mcd.

At Site U1314, a complete upper Pliocene to Holocene sequence, characterized by high sedimentation rates from 7 to $>11 \mathrm{~cm} / \mathrm{k} . y$. , was recovered. Because of its location close to the IRD belt and within the NADW, this section will be used to establish a high-resolution (millennial to submillennial) environmental record of sea-surface and bottom water characteristics and a detrital (Heinrich-type) stratigraphy for the past $\sim 2.7 \mathrm{~m} . \mathrm{y}$.

At Site U1315, a borehole observatory was successfully installed in a new $\sim 180 \mathrm{~m}$ deep hole close to Site 642 . This borehole observatory consists of a CORK to seal the borehole from the overlying ocean and a thermistor string/data logger unit to document BWT variations and monitor its subbottom diffusion over a 5 y period. To assess current background thermal conditions in the region, logging down to almost 600 mbsf was performed at Hole 642E, using the LDEO TAP tool in combination with the triple combo and FMS-sonic tool strings. The upper $10 \mathrm{~m}$ of the borehole has a very steep thermal gradient $\left(\sim 2500^{\circ} \mathrm{C} / \mathrm{km}\right)$. Below this depth, the borehole has a relatively low gradient of $\sim 22^{\circ} \mathrm{C} / \mathrm{km}$. At a depth of $\sim 500$ mbsf, a strong positive temperature excursion to $\sim 42^{\circ} \mathrm{C}$ may indicate inflow.

Although we lost 10 days to severe weather conditions with very strong winds up to hurricane force and could not reach the Eirik Drift as one of our main target areas because of the bad weather, Expedition 306 was successfully completed and most of the objectives outlined in the Expeditions 303 and 306 Scientific Prospectus and Addendum were fulfilled:

1. For the North Atlantic paleoceanography study we recovered complete sedimentary sections at three sites. These sections provide the require- 
ments, including adequate sedimentation rates, to study millennial-scale environmental variability in terms of ice sheet-ocean interactions, deep circulation changes, or sea-surface conditions. From the multidisciplinary studies to be performed on these cores (together with cores from Expedition 303) within the coming years, new milestones are expected in the understanding of mechanisms and causes of abrupt climate change as one of the major challenges in global climate change research today.

2. The second main objective of Expedition 306 was the CORK program. Here, a borehole observatory with a $150 \mathrm{~m}$ thermistor string was successfully deployed in a cased borehole fitted with a CORK close to Site 642. The data to be recovered within the following years will provide for the first time a directly measured record of BWT over the last $\sim 100$ y from a paleoceanographically important area of the North Atlantic.

The success of our expedition was substantially supported by the excellent cooperation between the IODP staff, the Transocean employees, and the Expedition 303/306 Scientists and the strong efforts of all of them.

\section{References}

Alley, R.B., Clark, P.U., Keigwin, L.D., and Webb, R.S., 1999. Making sense of millenial-scale climate change. In Clark, P.U., Webb, R.S., and Keigwin, L.D. (Eds.), Mechanisms of Global Climate Change at Millennial Time Scales. Geophys. Monogr., 112:385-394.

Antonov, J.I., 1993. Linear trends of temperature at intermediate and deep layers of the North Atlantic and North Pacific Oceans: 1957-1981. J. Climate, 6:19281942. doi:10.1175/1520-0442(1993)006<1928:LTOTAI >2.0.CO;2

Baldauf, J.G., Thomas, E., Clement, B., Takayama, T., Weaver, P.P.E., Backman, J., Jenkins, G., Mudie, P.J., and Westberg-Smith, M.J., 1987. Magnetostratigraphic and biostratigraphic synthesis, Deep Sea Drilling Project Leg 94. In Ruddiman, W.F., Kidd, R.B., Thomas, E., et al., Init. Repts. DSDP, 94 (Pt. 2): Washington (U.S. Govt. Printing Office), 1159-1205.

Baumgartner, S., Beer, J., Masarik, J., Wagner, G., Meynadier, L., and Synal, H.-A., 1998. Geomagnetic modulation of the ${ }^{36} \mathrm{Cl}$ flux in the GRIP ice core. Science, 279:1330-1332. doi:10.1126/science.279.5355.1330

Bond, G., Heinrich, H., Broecker, W., Labeyrie, L.D., McManus, J., Andrews, J., Huon, S., Jantschik, R., Clasen, S., Simet, C., Tedesco, K., Klas, M., Bonani, G., and Ivy, S., 1992. Evidence for massive discharges of icebergs into the North Atlantic Ocean during the last glacial period. Nature (London, U. K.), 360:245-249. doi:10.1038/360245a0
Bond, G., Kromer, B., Beer, J., Muscheler, R., Evans, M.N., Showers, W., Hoffmann, S., Lotti-Bond, R., Hajdas, I., and Bonani, G., 2001. Persistent solar influence on North Atlantic climate during the Holocene. Science, 294:2130-2136. doi:10.1126/science.1065680

Bond, G., Showers, W., and Lynch-Stieglitz, J., 1999a. Are major shifts in thermohaline circulation revealed in North Atlantic and South Atlantic antiphased patterns? Eos, Trans. Am. Geophys. Union, 80:S169. (Abstract)

Bond, G.C., Broecker, W., Johnsen, S., McManus, J., Labeyrie, L., Jouzel, J., and Bonani, G., 1993. Correlations between climate records from North Atlantic sediments and Greenland ice. Nature (London, U. K.), 365:143-147. doi:10.1038/365143a0

Bond, G.C., and Lotti, R., 1995. Iceberg discharges into the North Atlantic on millennial timescales during the last glaciation. Science, 276:1005-1010.

Bond, G.C., Showers, W., Elliot, M., Evans, M., Lotti, R., Hajdas, I., Bonani, G., and Johnson, S., 1999b. The North Atlantic's 1-2 kyr climate rhythm: relation to Heinrich events, Dansgaard/Oeschger cycles and the Little Ice Age. In Clark, P.U., Webb, R.S., and Keigwin, L.D. (Eds.), Mechanisms of Global Climate Change at Millennial Time Scales. Geophys. Monogr., 112:35-58.

Broecker, W.S., 1987. Unpleasant surprises in the greenhouse? Nature (London, U. K.), 328:123-126. doi:10.1038/328123a0

Campbell, I.D., Campbell, C., Apps, M.J., Rutter, N.W., and Bush, A.B.G., 1998. Late Holocene $\sim 1500$ yr climatic periodicities and their implications. Geology, 26:471473. doi:10.1130/0091-7613(1998)026<0471:LHY$\mathrm{CPA}>2.3 . \mathrm{CO} ; 2$

Carlut, J., and Courtillot, V., 1998. How complex is the time-averaged geomagnetic field over the past 5 myr? Geophys. J. Int., 134:527-544. doi:10.1046/j.1365246x.1998.00577.x

Calvo, E., Villanueva, J., Grimalt, J.O., Boelaert, A., and Labeyrie, L., 2001. New insights into the glacial latitudinal temperature gradients in the North Atlantic. Results from $\mathrm{U}^{\mathrm{k}}{ }_{37}$ sea surface temperatures and terrigenous inputs. Earth Planet. Sci. Lett., 188:509-519. doi:10.1016/S0012-821X(01)00316-8

Cande, S.C., and Kent, D.V., 1995. Revised calibration of the geomagnetic polarity timescale for the Late Cretaceous and Cenozoic. J. Geophys. Res., 100:6093-6095. doi:10.1029/94JB03098

Channell, J.E.T., Hodell, D.A., McManus, J., and Lehman, B., 1998. Orbital modulation of the Earth's magnetic field intensity. Nature (London, U. K.), 394:464-468. doi:10.1038/28833

Channell, J.E.T., and Lehman, B., 1997. The last two geomagnetic polarity reversals recorded in high-depositionrate sediment drifts. Nature (London, U. K.), 389:712715. doi:10.1038/39570

Channell, J.E.T., Mazaud, A., Sullivan, P., Turner, S., and Raymo, M.E., 2002. Geomagnetic excursions and paleointensities in the Matuyama Chron at ODP Sites 983 and 984 (Iceland Basin). J. Geophys. Res., 107. doi:10.1029/2001JB000491 
Channell, J.E.T., Sato, T., Kanamatsu, T., Stein, R., Malone, M.J., and the Expedition 303/306 Project Team, 2004. North Atlantic climate. IODP Sci. Prosp., 303/306. doi:10.2204/iodp.sp.303306.2004

Channell, J.E.T., Stoner, J.S., Hodell, D.A., and Charles, C.D., 2000. Geomagnetic paleointensity for the last 100 kyr from the sub-antarctic South Atlantic: a tool for inter-hemispheric correlation. Earth Planet. Sci. Lett., 175:145-160. doi:10.1016/S0012-821X(99)00285-X

Chapman, D.S., and Harris, R.N., 1993. Repeat temperature measurements in Borehole GC-1, northwestern Utah: towards isolating a climate-change signal in borehole temperature profiles. Geophys. Res. Lett., 18:1891-1894.

Clark, P.U., Webb, R.S., and Kleigwin, L.D., (Eds.), 1999. Mechanisms of Global Climate Change at Millenial Time Scales. Geophys. Monogr., Vol. 112.

CLIMAP Project Members, 1976. The surface of the ice-age Earth. Science, 191:1131-1137.

Coe, R.S., Hongre, L., and Glatzmaier, G.A., 2000. An examination of simulated geomagnetic reversals from a palaeomagnetic perspective. Philos. Trans. R. Soc. London, Ser. A, 358:1141-1170.

Crowley, T.J., 1999. Correlating high-frequency climate variations. Paleoceanography, 14:271-272. doi:10.1029/ 1999PA900003

deMenocal, P., Ortiz, J., Guilderson, T., and Sarnthein, M., 2000. Coherent high- and low-latitude variability during the Holocene warm period. Science, 288:2198-2202. doi:10.1126/science.288.5474.2198

Dickson, B., 1997. From the Labrador Sea to global change. Nature (London, U. K.), 386:649-650. doi:10.1038/ 386649a0

Eldholm, O., Thiede, J., Taylor, E., et al., 1987. Proc. ODP, Init. Repts., 104: College Station, TX (Ocean Drilling Program).

Flower, B.P., Oppo, D.W., McManus, J.F., Venz, K.A., Hodell, D.A., and Cullen, J., 2000. North Atlantic Intermediate to Deep Water circulation and chemical stratification during the past 1 myr. Paleoceanography, 15:388403. doi:10.1029/1999PA000430

Frank, M., Schwarz, B., Baumann, S., Kubik, P.W., Suter, M., and Mangini, A., 1997. A 200 kyr record of cosmogenic radionuclide production rate and geomagnetic field intensity from ${ }^{10} \mathrm{Be}$ in globally stacked deep-sea sediments. Earth Planet. Sci. Lett., 149:121-129. doi:10.1016/S0012-821X(97)00070-8

Gammelsrød, T., Østerhus, S., and Godøy, Ø., 1992. Decadal variations of ocean climate in the Norwegian Sea at Ocean Station 'Mike' ( $65^{\circ} \mathrm{N} 2^{\circ}$ E). ICES J. Mar. Sci., 195:68-75.

Glatzmaier, G.A., and Roberts, P.H., 1995. A three-dimensional self-consistent computer-simulation of a geomagnetic-field reversal. Nature (London, U. K.), 377:203-209. doi:10.1038/377203a0

Gubbins, D., 1999. The distinction between geomagnetic excursions and reversals. Geophys. J. Int., 137:F1-F3. doi:10.1046/j.1365-246x.1999.00810.x

Guyodo, Y., Gaillot, P., and Channell, J.E.T., 2000. Wavelet analysis of relative geomagnetic paleointensity at ODP
Site 983. Earth Planet. Sci. Lett., 184:109-123. doi:10.1016/S0012-821X(00)00313-7

Guyodo, Y., and Valet, J.-P., 1996. Relative variations in geomagnetic intensity from sedimentary records: the past 200,000 years. Earth. Planet. Sci. Lett., 143:23-36. doi:10.1016/0012-821X(96)00121-5

Hongre, L., Hulot, G., and Khokhlov, A., 1998. An analysis of the geomagnetic field over the past 2000 years. Phys. Earth Planet. Inter., 106:311-335.

Hulot, G., and Le Mouël, J.-L., 1994. A statistical approach to the Earth's main magnetic field. Phys. Earth Planet. Inter., 82:167-183.

Johnson, C.L., and Constable, C.G., 1997. The time-averaged geomagnetic field: global and regional biases for 0 5 Ma. Geophys. J. Int., 131:643-666.

Kanamatsu, T., Stein, R., and Alvarez Zarikian, C.A., 2005. North Atlantic climate II addendum. IODP Sci. Prosp., 306 Add. doi:10.2204/iodp.sp.303306add.2005

Keigwin, L.D., Rio, D., Acton, G.D., and Arnold, E. (Eds.), 2001. Proc. ODP, Sci. Results, 172 [CD-ROM]. Available from: Ocean Drilling Program, Texas A\&M University, College Station TX 77845-9547, USA. [HTML]

Kelly, P., and Gubbins, D., 1997. The geomagnetic field over the past 5 million years. Geophys. J. Int., 128:315330.

Kissel, C., Laj, C., Labeyrie, L., Dokken, T., Voelker, A., and Blamart, D., 1999. Rapid climatic variations during marine isotopic Stage 3: magnetic analysis of sediments from Nordic Seas and North Atlantic. Earth Planet. Sci. Lett., 171:489-502. doi:10.1016/S0012821X(99)00162-4

Kleiven, H.F., Jansen, E., Curry, W.B., Hodell, D.A., and Venz, K., 2003, Atlantic Ocean thermohaline circulation changes on orbital to suborbital timescales during the mid-Pleistocene. Paleoceanography, 18. doi:10.1029/ 2001PA000629

Labeyrie, L., Jansen, E., and Cortijo, E., 2003. MD114/ IMAGES V cruise report, OCE/2003/02: (Institut Polaire Francais Paul-Émile Victor).

Laj, C., Kissel, C., Mazaud, A., Channell, J.E.T., and Beer, J., 2000. North Atlantic paleointensity stack since $75 \mathrm{ka}$ (NAPIS-75) and the duration of the Laschamp Event. Phil. Trans. R. Soc. Lond., 358:1009-1025.

Lisiecki, L.E., and Raymo, M.E., 2005. A PliocenePleistocene stack of 57 globally distributed benthic $\delta^{18} \mathrm{O}$ records. Paleoceanography, 20. doi:10.1029/ 2004PA001071

Lund, S.P., Acton, G., Clement, B., Hastedt, M., Okada, M., and Williams, T., 1998. Geomagnetic field excursions occurred often during the last million years. Eos, Trans. Am. Geophys. Union, 79:178-179.

Lund, S.P., Acton, G.D., Clement, B., Okada, M., and Williams, T., 2001a. Paleomagnetic records of Stage 3 excursions, Leg 172. In Keigwin, L.D., Rio, D., Acton, G.D., and Arnold, E. (Eds.), Proc. ODP, Sci. Results, 172, 1-20 [Online]. Available from World Wide Web: http:// www-odp.tamu.edu/publications/172_SR/VOLUME/ CHAPTERS/SR172_11.PDF. 
Lund, S.P., Williams, T., Acton, G., Clement, B., and Okada, M., 2001b. Brunhes Chron magnetic-field excursions recovered from Leg 172 sediments. In Keigwin, L.D., Rio, D., Acton, G.D., and Arnold, E. (Eds.), Proc. ODP, Sci. Results, 172 [Online]. Available from World Wide Web: http://www-odp.tamu.edu/publications/ 172_SR/chap_10/chap_10.htm.

Mazaud, A., Laj, C., and Bender, M., 1994. A geomagnetic chronology for Antarctic ice accumulation. Geophys. Res. Lett., 21:337-340. doi:10.1029/93GL02789

McManus, J.F., Bond, G.C., Broecker, W.S., Johnsen, S., Labeyrie, L., and Higgins, S., 1994. High-resolution climate records from the North Atlantic during the last interglacial. Nature (London, U. K.), 371:326-329. doi:10.1038/371326a0

McManus, J.F., Oppo, D.W., and Cullen, J.L., 1999. A 0.5 million year record of millennial-scale climate variability in the North Atlantic. Science, 283:971-975. doi:10.1126/science.283.5404.971

Meynadier, L., Valet, J.-P., Weeks, R.J., Shackleton, N.J., and Hagee, V.L., 1992. Relative geomagnetic intensity of the field during the last $140 \mathrm{ka}$. Earth Planet. Sci. Lett., 114:39-57. doi:10.1016/0012-821X(92)90150-T

Mudelsee, M., and Schultz, M., 1997. The mid-Pleistocene climate transition: onset of $100 \mathrm{ka}$ cycle lags ice volume built-up by 280 ka. Earth Planet. Sci. Lett., 151:117-123. doi:10.1016/S0012-821X(97)00114-3

Oppo, D.W., McManus, J.F., and Cullen, J.L., 1998. Abrupt climate events 500,000 to 340,000 years ago: evidence from subpolar North Atlantic sediments. Science, 279:1335-1338. doi:10.1126/science.279.5355.1335

Pflaumann, U., Sarnthein, M., Chapman, M., de Abreu, L., Funnell, B., Huels, M., Kiefer, T., Maslin, M., Schulz, H., Swallow, J., van Kreveld, S., Vautravers, M., Vogelsang, E., and Weinelt, M., 2003. Glacial North Atlantic: seasurface conditions reconstructed by GLAMAP 2000. Paleoceanography, 18(3). doi:10.1029/2002PA000774

Poli, M.S., Thunell, R.C., and Rio, D., 2000. Millennialscale changes in North Atlantic Deep Water circulation during marine isotope Stages 11 and 12: linkage to Antarctic climate. Geology, 28:807-810. doi:10.1130/00917613(2000)028<0807:MSCINA >2.3.CO;2

Raisbeck, G.M., Yiou, F., Bourles, D., Lorius, C., Jouzel, J., and Barkov, N.I., 1987. Evidence for two intervals of enhanced ${ }^{10} \mathrm{Be}$ deposition in Antarctic ice during the last glacial period. Nature (London, U.K.), 326:273-277. doi:10.1038/326273a0

Raymo, M.E., 1999. Appendix. New insights into Earth's history: an introduction to Leg 162 postcruise research published in journals. In Raymo, M.E., Jansen, E., Blum, P., and Herbert, T.D. (Eds.), Proc. ODP, Sci. Results, 162: College Station, TX (Ocean Drilling Program), 273-275. [HTML]

Raymo, M.E., Ganley, K., Carter, S., Oppo, D.W., and McManus, J., 1998. Millenial-scale climate instability during the early Pleistocene epoch. Nature (London, $U$. K.), 392:699-702. doi:10.1038/33658

Raymo, M.E., Oppo, D.W., Flower, B.P., Hodell, D.A., McManus, J.F., Venz, K.A., Kleiven, K.F., and McIntyre, K., 2004. Stability of North Atlantic water masses in face of pronounced climate variability during the Pleistocene. Paleoceanography, 19. doi:10.1029/ 2003PA000921

Raymo, M.E., Ruddiman, W.F., Backman, J., Clement, B.M., and Martinson, D.G., 1989. Late Pliocene variation in northern hemisphere ice sheets and North Atlantic Deep Water circulation. Paleoceanography, 4:413-446.

Rio, D., and Arnold, E. (Eds.), 2002. Mar. Geo., 189(1-2):1174.

Roemmich, D., and Wunsch, C., 1984. Apparent changes in the climatic state of the deep North Atlantic Ocean. Nature (London, U. K.), 307:447-450. doi:10.1038/ $307447 \mathrm{aO}$

Ruddiman, W.F., Kidd, R.B., Thomas, E., et al., 1987. Init. Repts. DSDP, 94 (Pts. 1 and 2): Washington (U.S. Govt. Printing Office).

Ruddiman, W.F., Raymo, M., and McIntyre, A., 1986. Matuyama 41,000-year cycles: North Atlantic Ocean and northern hemisphere ice sheets. Earth Planet. Sci. Lett., 80:117-129. doi:10.1016/0012-821X(86)90024-5

Ruddiman, W.F., Raymo, M.E., Martinson, D.G., Clement, B.M., and Backman, J., 1989. Pleistocene evolution: northern hemisphere ice sheets and North Atlantic Ocean. Paleoceanography, 4:353-412.

Sarnthein, M., Stattegger, K., Dreger, D., Erlenkeuser, H., Grootes, P., Haupt, B.J., Jung, S., Kiefer, T., Kuhnt, W., Pflaumann, U., Schäfer-Neth, C., Schulz, H., Schulz, M., Seidov, D., Simstich, J., van Kreveld, S., Vogelsang, E., Völker, A., and Weinelt, M., 2000. Fundamental modes and abrupt changes in North Atlantic circulation and climate over the last $60 \mathrm{ky}$-concepts, reconstruction and numerical modeling. In Schäfer, P., Ritzrau, W., Schlüter, M., and Thiede, J. (Eds.), The Northern Atlantic: A Changing Environment: Berlin (Springer), 365-410.

Schmieder, F., von Dobeneck, T., and Bleil, U., 2000. The mid-Pleistocene climate transition as documented in the deep South Atlantic Ocean: initiation, interim state and terminal event. Earth Planet. Sci. Lett., 179:539-549. doi:10.1016/S0012-821X(00)00143-6

Shipboard Scientific Party, 2005. North Atlantic climate: ice sheet-ocean atmosphere interactions on millennial timescales during the late Neogene-Quaternary using a paleointensity-assisted chronology for the North Atlantic. IODP Prel. Rept., 303. doi:10.2204/ iodp.pr.303.2005

Sirocko, F., Garbe-Schönberg, D., McIntyre, A., and Molfino, B., 1996. Teleconnections between the subtropical monsoons and high-latitude climates during the last deglaciation. Science, 272:526-529.

Stoner, J.S., Channell, J.E.T., and Hillaire-Marcel, C., 1998. A 200 ka geomagnetic chronostratigraphy for the Labrador Sea: indirect correlation of the sediment record to SPECMAP. Earth Planet. Sci. Lett., 159:165-181. doi:10.1016/S0012-821X(98)00069-7

Stoner, J.S., Channell, J.E.T., Hillaire-Marcel, C., and Kissel, C., 2000. Geomagnetic paleointensity and environmental record from Labrador Sea Core MD95-2024: global marine sediment and ice core chronostratigraphy for the last 110 kyr. Earth Planet. Sci. Lett., 183:161-177. doi:10.1016/S0012-821X(00)00272-7 
Stoner, J.S., Laj, C., Channell, J.E.T., and Kissel, C., 2002. South Atlantic (SAPIS) and North Atlantic (NAPIS) geomagnetic paleointensity stacks (0-80 ka): implications for inter-hemispheric correlation. Quat. Sci. Rev., 21:1142-1151.

van Kreveld, S., Sarnthein, M., Erlenkeuser, H., Grootes, P., Jung, S., Nadeau, M.J., Pflaumann, U., and Voelker, A., 2000. Potential links between surging ice sheets, circulation changes and the Dansgaard-Oeschger cycles in the Irminger Sea, 60-18 kyr. Paleoceanography, 15:425-442. doi:10.1029/1999PA000464

Voelker, A.H.L., Sarnthein, M., Grootes, P.M., Erlenkeuser, H., Laj, C., Mazaud, A., Nadeau, M.-J., and Schleicher, M., 1998. Correlation of marine ${ }^{14} \mathrm{C}$ ages from the Nordic Seas with the GISP2 isotope record: implications for ${ }^{14} \mathrm{C}$ calibration beyond 25 ka BP. Radiocarbon, 40:517-534.
Wood, R.A., Keen, A.B., Mitchell, J.R.B., and Gregory, J.M., 1999. Changing spatial structure of thermohaline circulation in response to atmospheric $\mathrm{CO}_{2}$ forcing in a climate model. Nature (London, U. K.), 399:572-575. doi:10.1038/21170

Wunsch, C., 1992. Decade-to-century changes in the ocean circulation. Oceanography, 5:99-106.

Yamazaki, T., 1999. Relative paleointensity of the geomagnetic field during Brunhes Chron recorded in North Pacific deep-sea sediment cores: orbital influence? Earth Planet. Sci. Lett., 169:23-35. doi:10.1016/S0012821X(99)00064-3

Publication: 9 September 2006 MS 306-109 
Figure F1. Expedition 303 and 306 site locations.

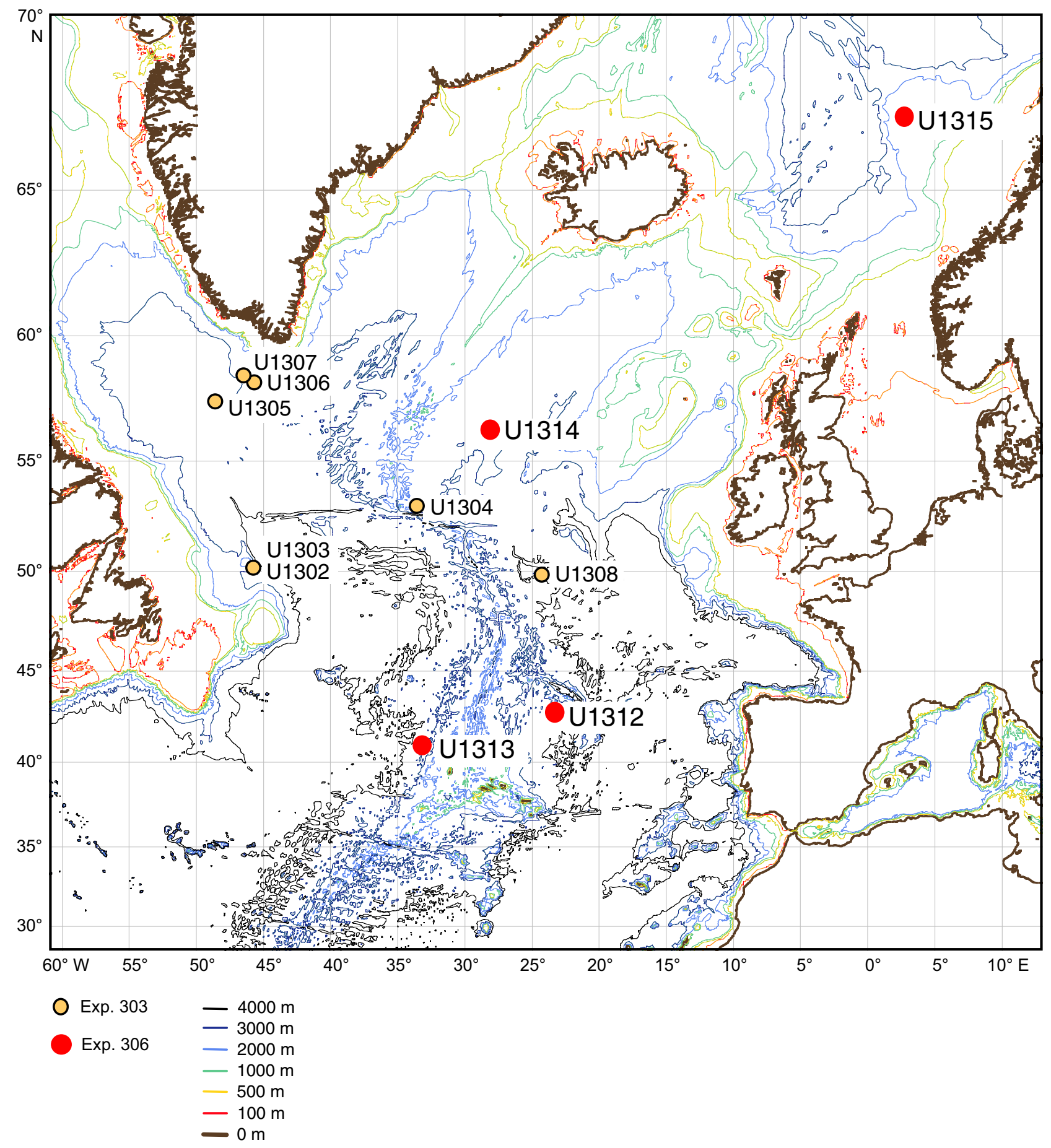


Figure F2. Modern circulation in the North Atlantic, Expedition 303 (blue) and 306 (red) and Leg 162 (yellow) site locations, and distribution of rock types that are potential source areas of detrital carbonate. Large blue arrows = pathways of detrital matter supplied during Heinrich events, gray field = Ruddiman's IRD belt (from Bond and Lotti [1995], supplemented).

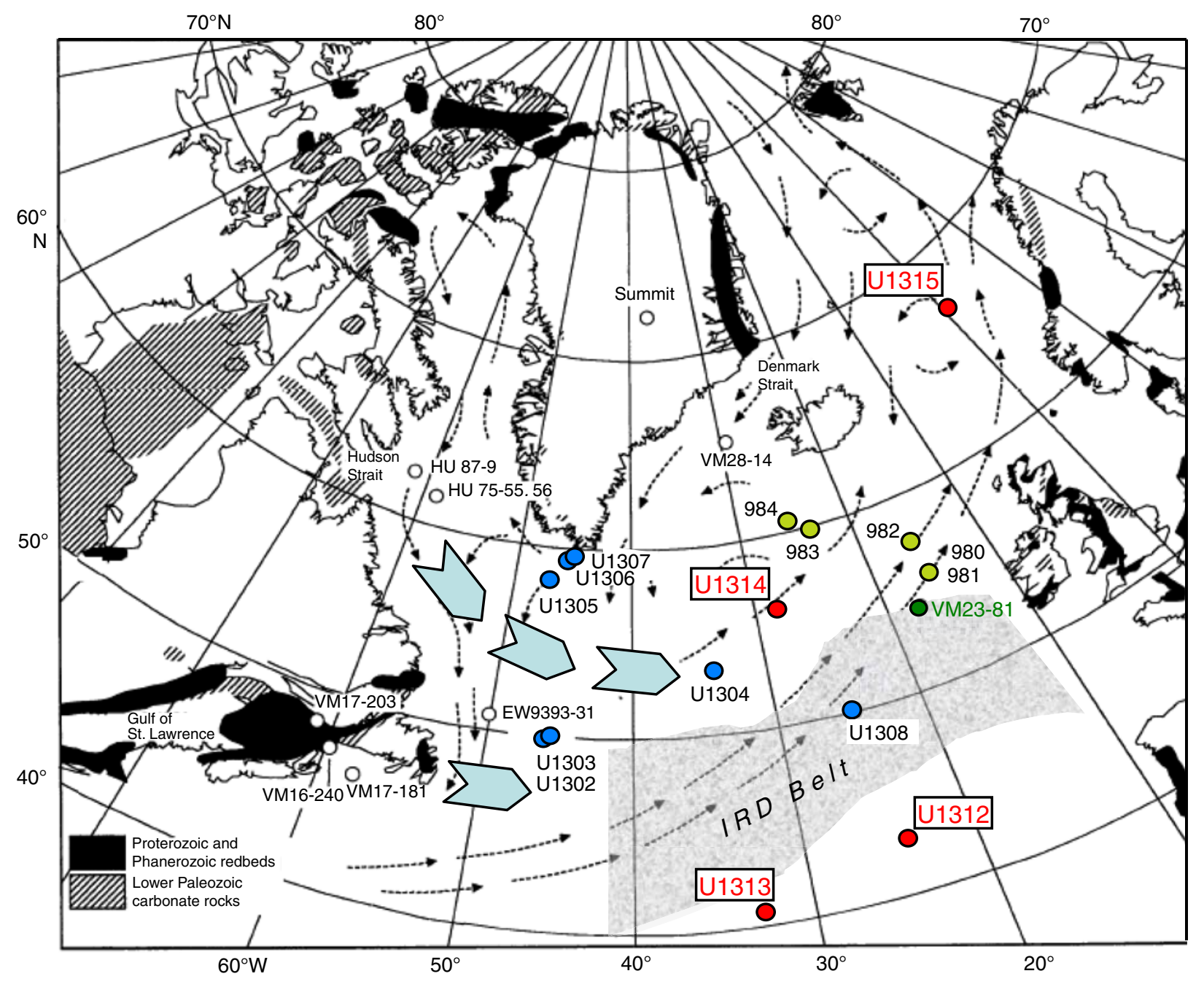


Figure F3. Location map of Norwegian Sea and Vøring Plateau showing Site 642 and Ocean Weather Ship Station (OWS) station Mike (modified from Gammelsrød et al., 1992).

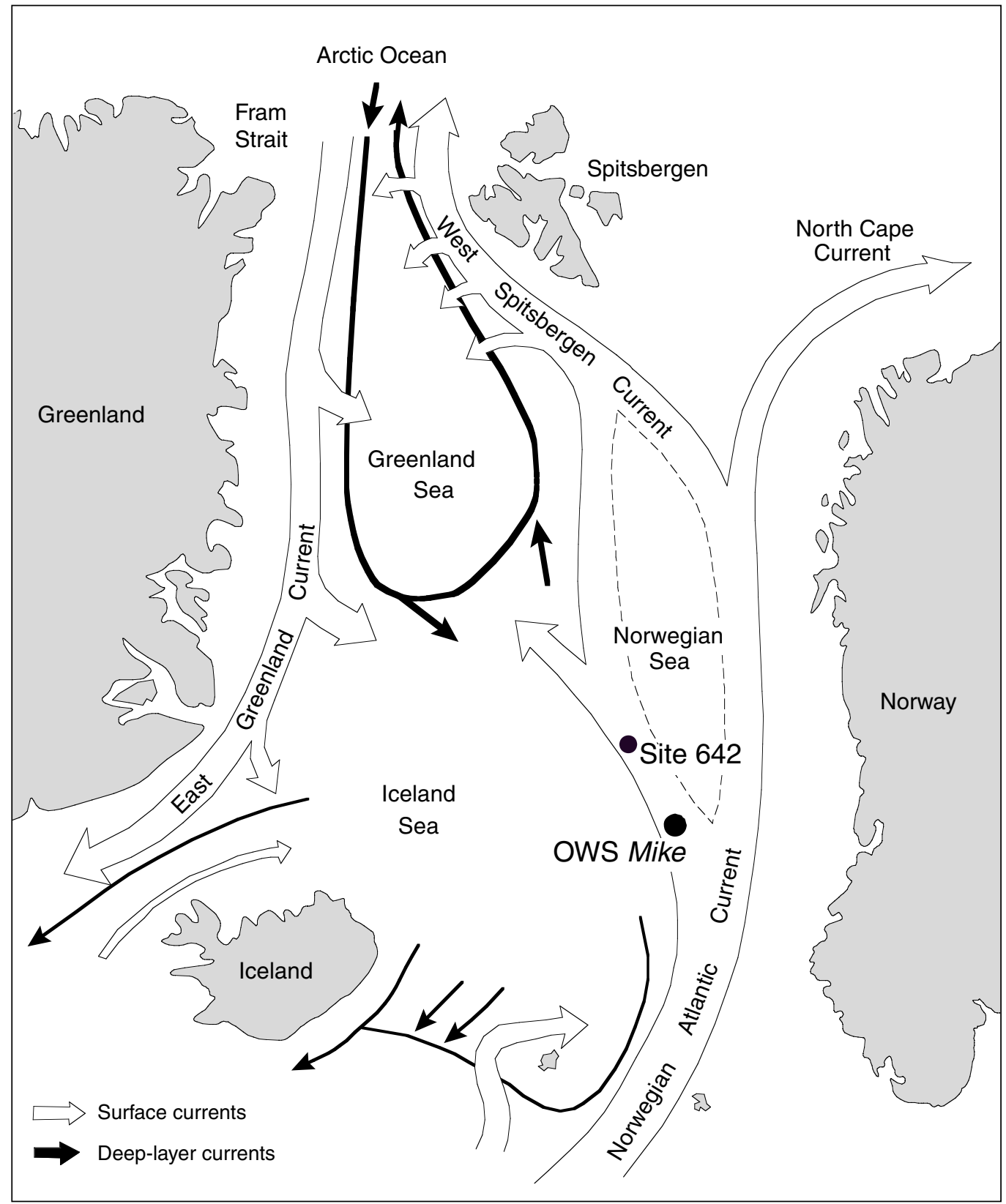


Figure F4. Lithostratigraphy of Sites U1312, U1313, and U1314.

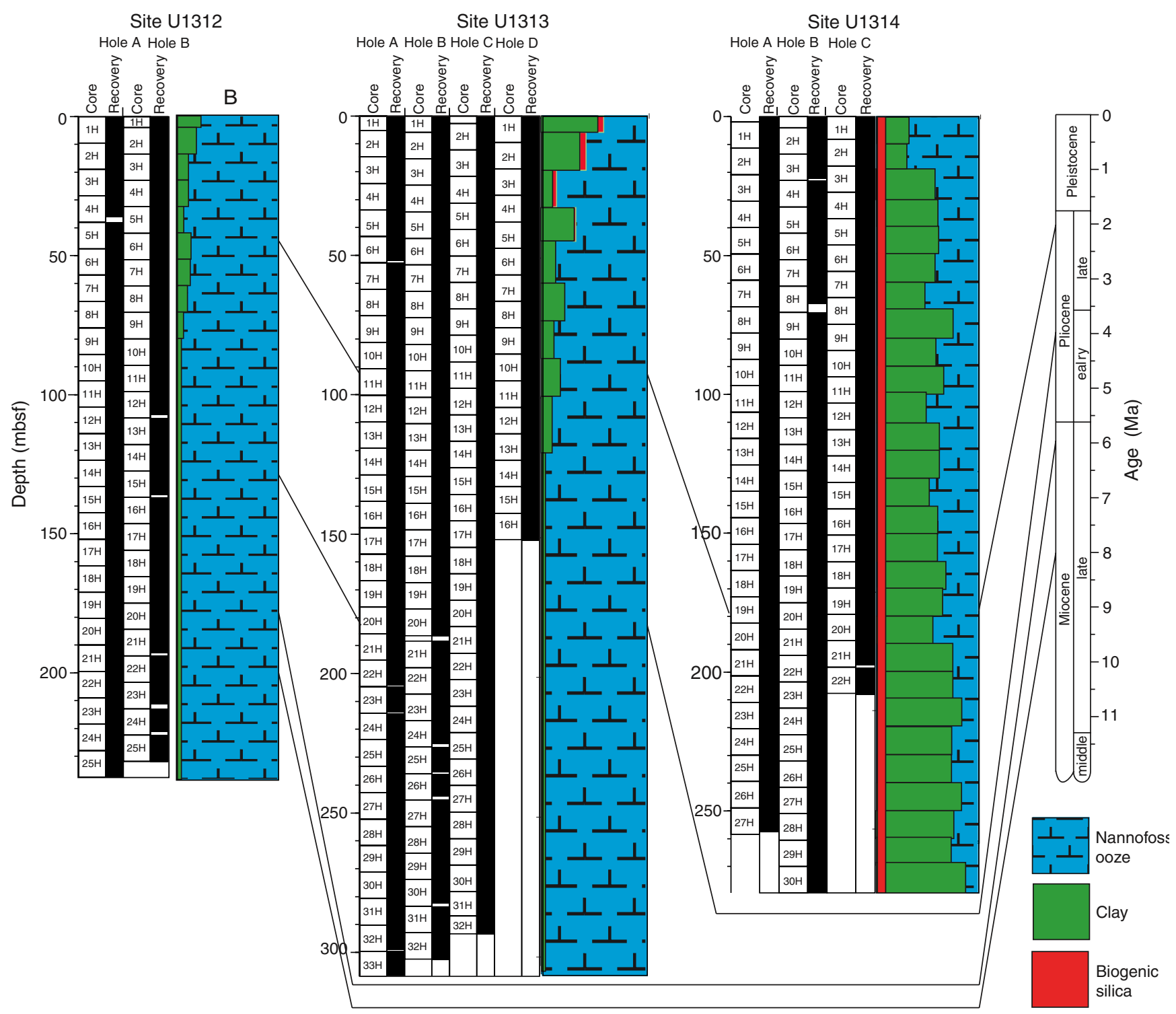


Figure F5. Sedimentation rates at sites drilled during Expedition 306. Open squares = magnetostratigraphybased ages, solid circles $=$ nannofossil-based ages, solid triangles $=$ foraminifer-based ages, solid squares $=$ diatom-based ages, solid diamonds = radiolarian-based ages. Mean sedimentation rates calculated for straightline segments. Unreliable points are faded and not used for calculation of sedimentation rates. These points are events that may be reworked, may not represent true first or last occurrences due to distribution limits within different water masses, or resulted in incongruous depths when plotted on the mcd scale.

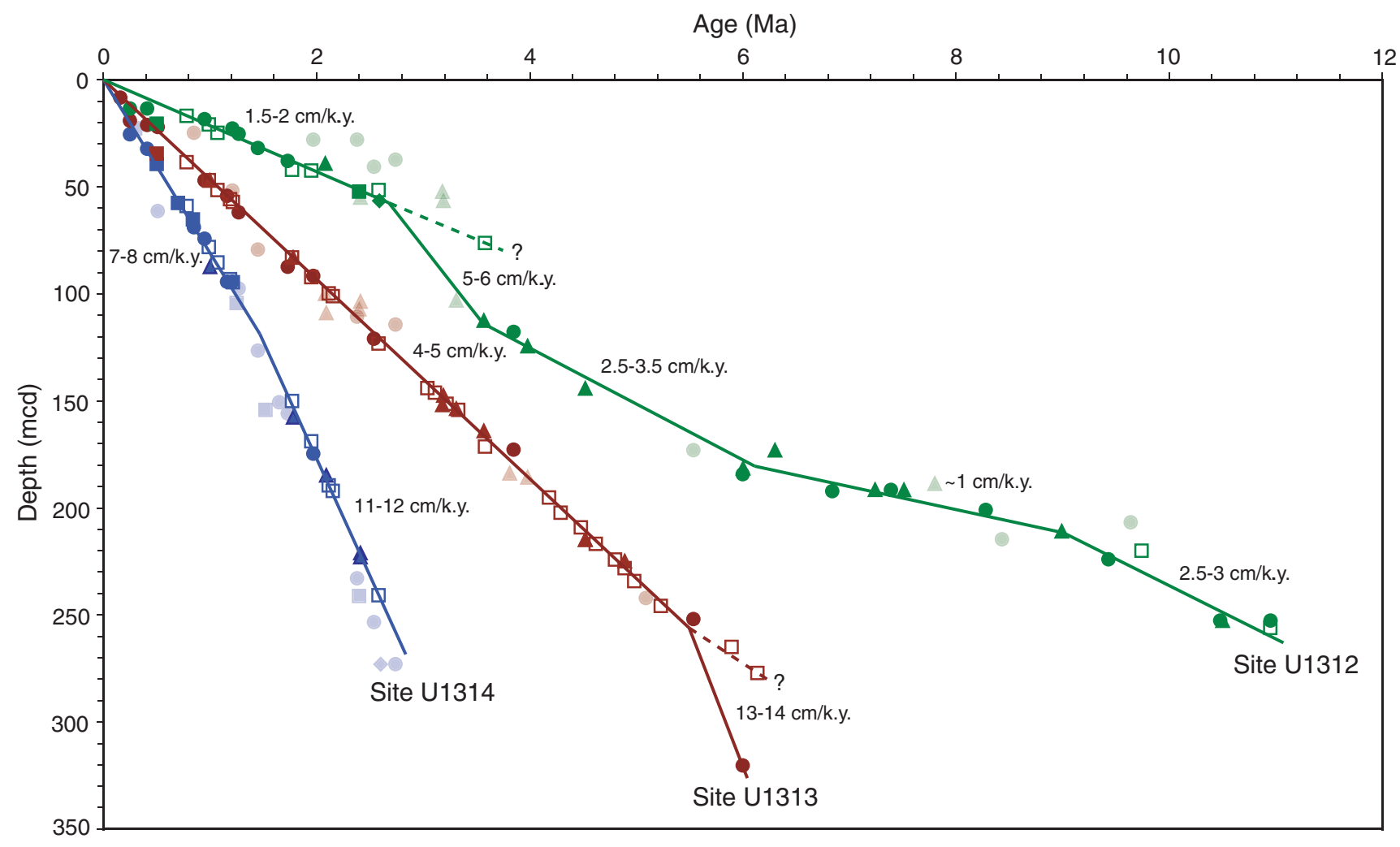


Figure F6. Magnetostratigraphy versus depth. The paleomagnetic polarity interpretations (black = normal polarity, white $=$ reversed polarity, gray $=$ undetermined polarity) were obtained on the basis of inclination data acquired after $20 \mathrm{mT}$ AF demagnetization. The reference geomagnetic polarity timescale is displayed on the right side of the figure (Cande and Kent, 1995). Continuous blue lines indicate the main tie points used to establish the age models.

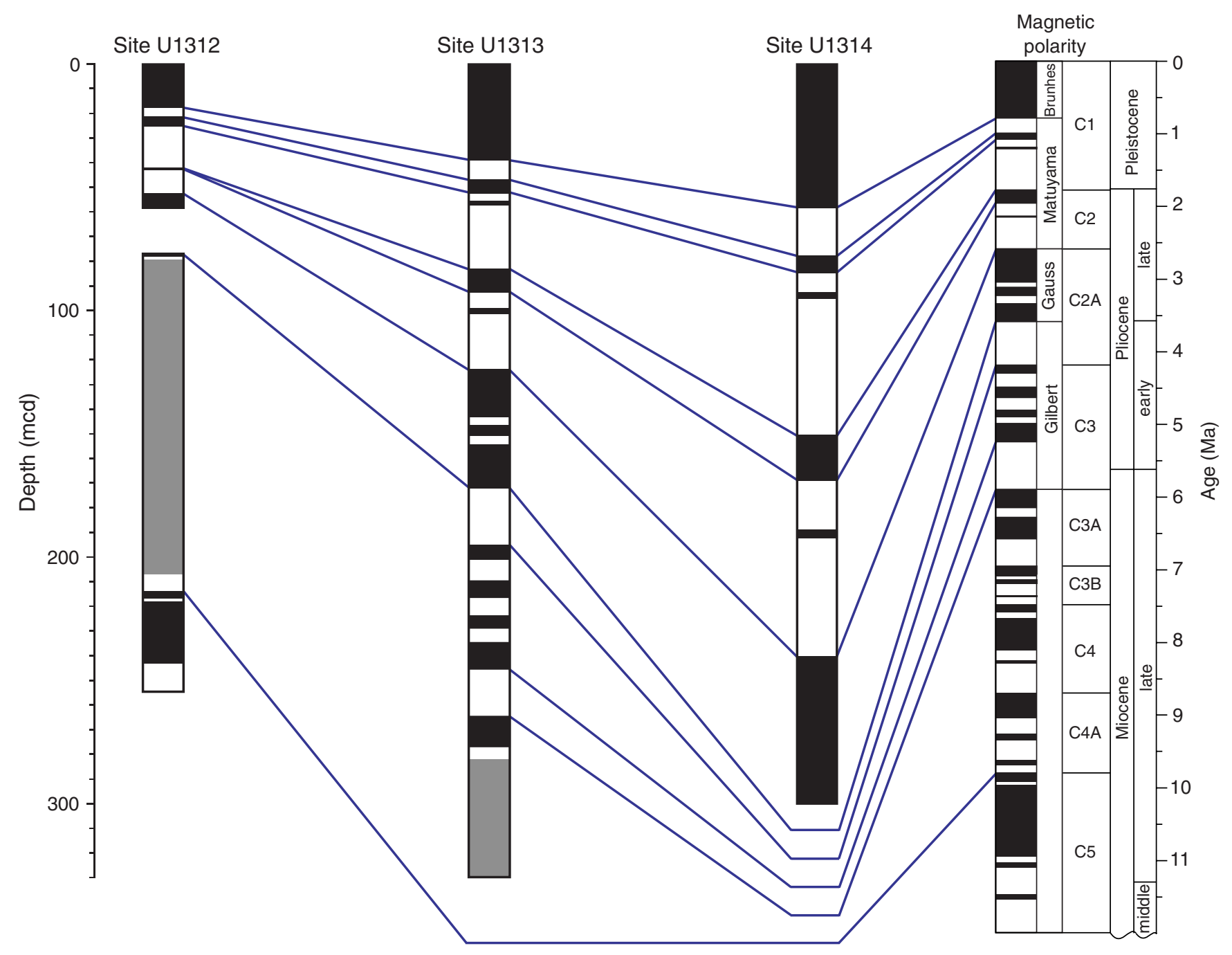


Figure F7. Natural gamma radiation (NGR) counts, magnetic susceptibility, and gamma ray attenuation (GRA) density measurements from the MST and archive multisensor track (AMST) reflectance values in the sedimentary record of Site U1312.

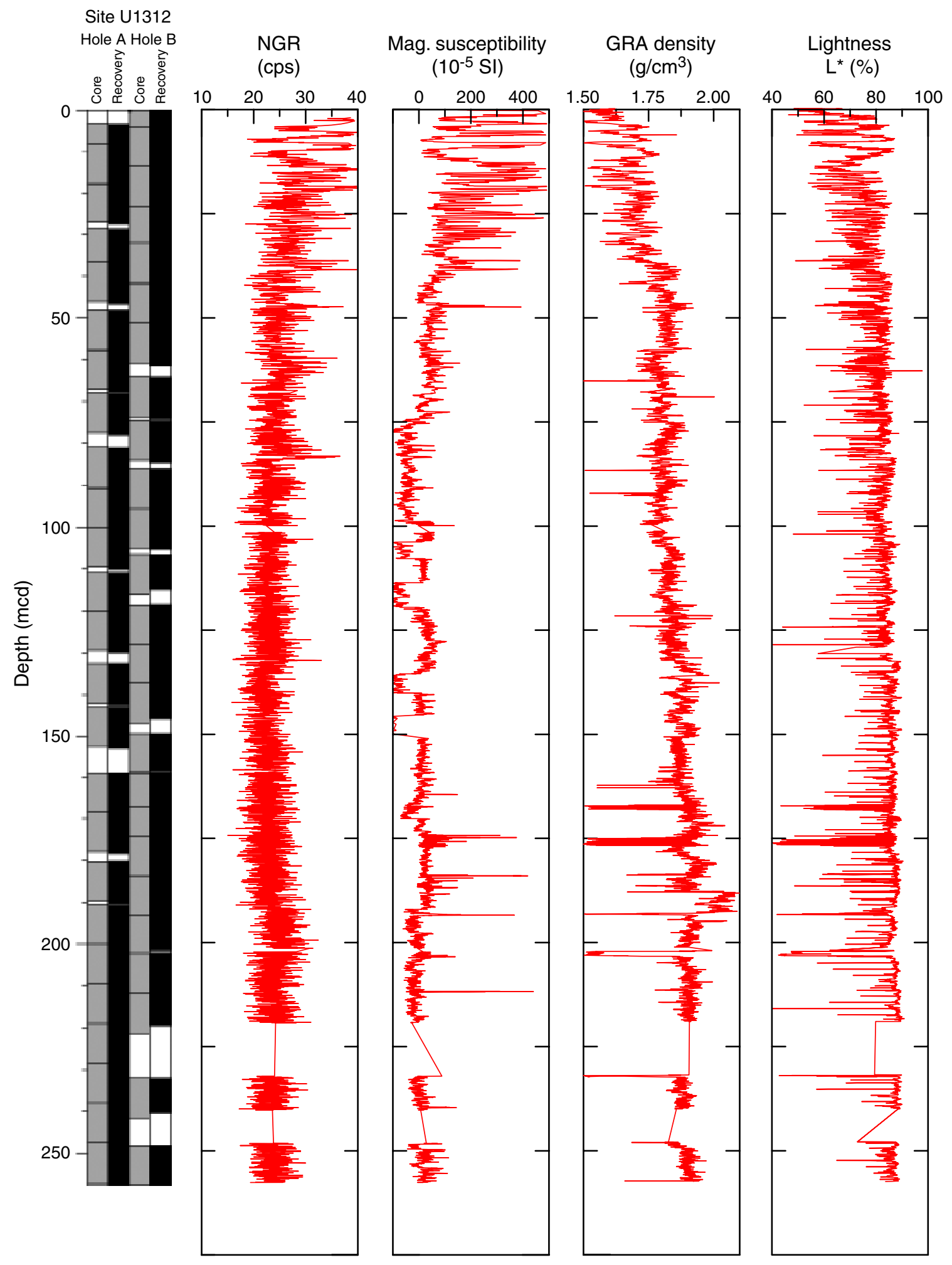


Figure F8. Natural gamma radiation (NGR) counts, magnetic susceptibility, and gamma ray denotation (GRA) density measurements from the MST and archive multisensor track (AMST) reflectance values in the sedimentary record of Site U1313.

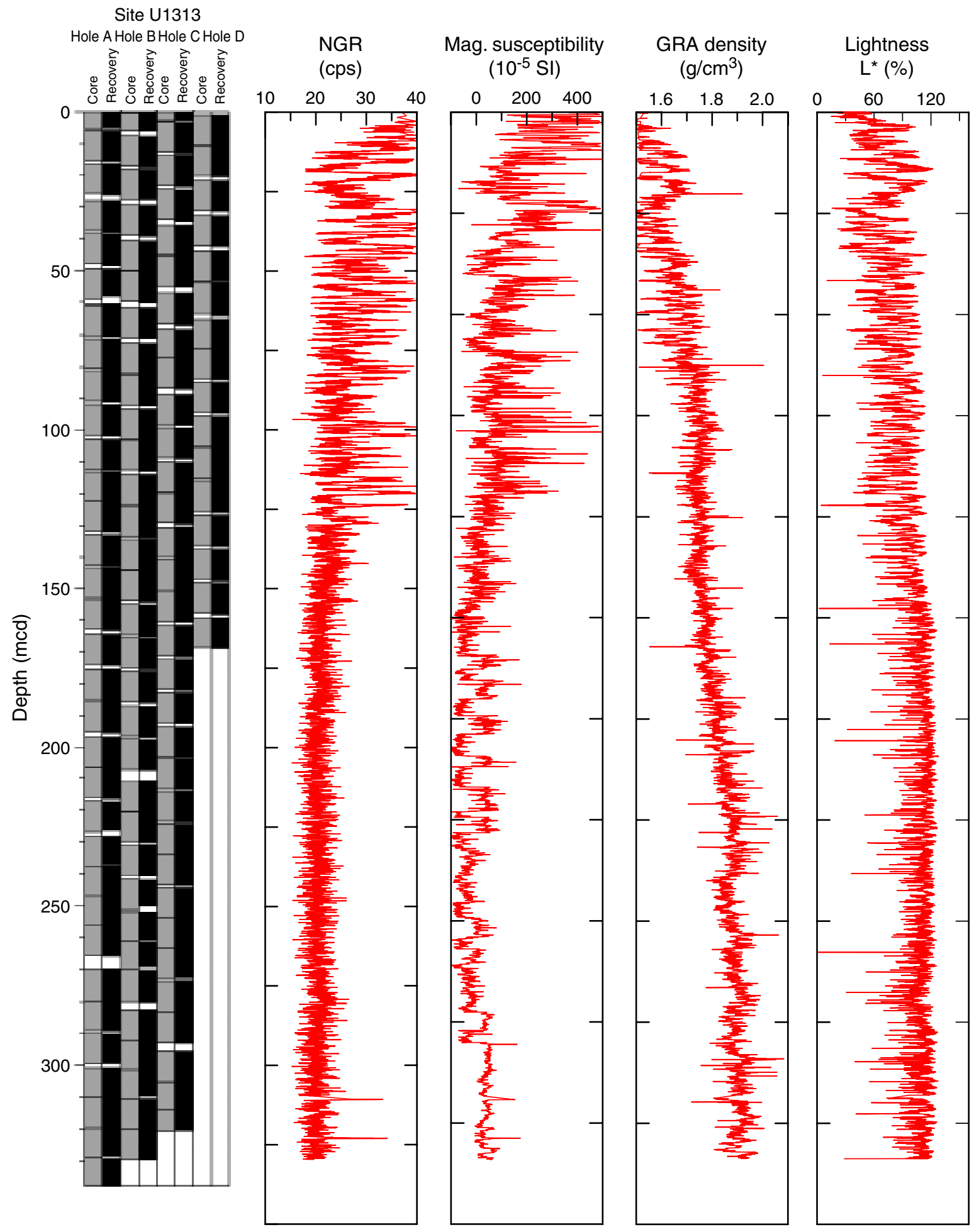


Figure F9. Natural gamma radiation (NGR) counts, magnetic susceptibility, and gamma ray denotation (GRA) density measurements from the MST and archive multisensor track (AMST) reflectance values in the sedimentary record of Site U1314.

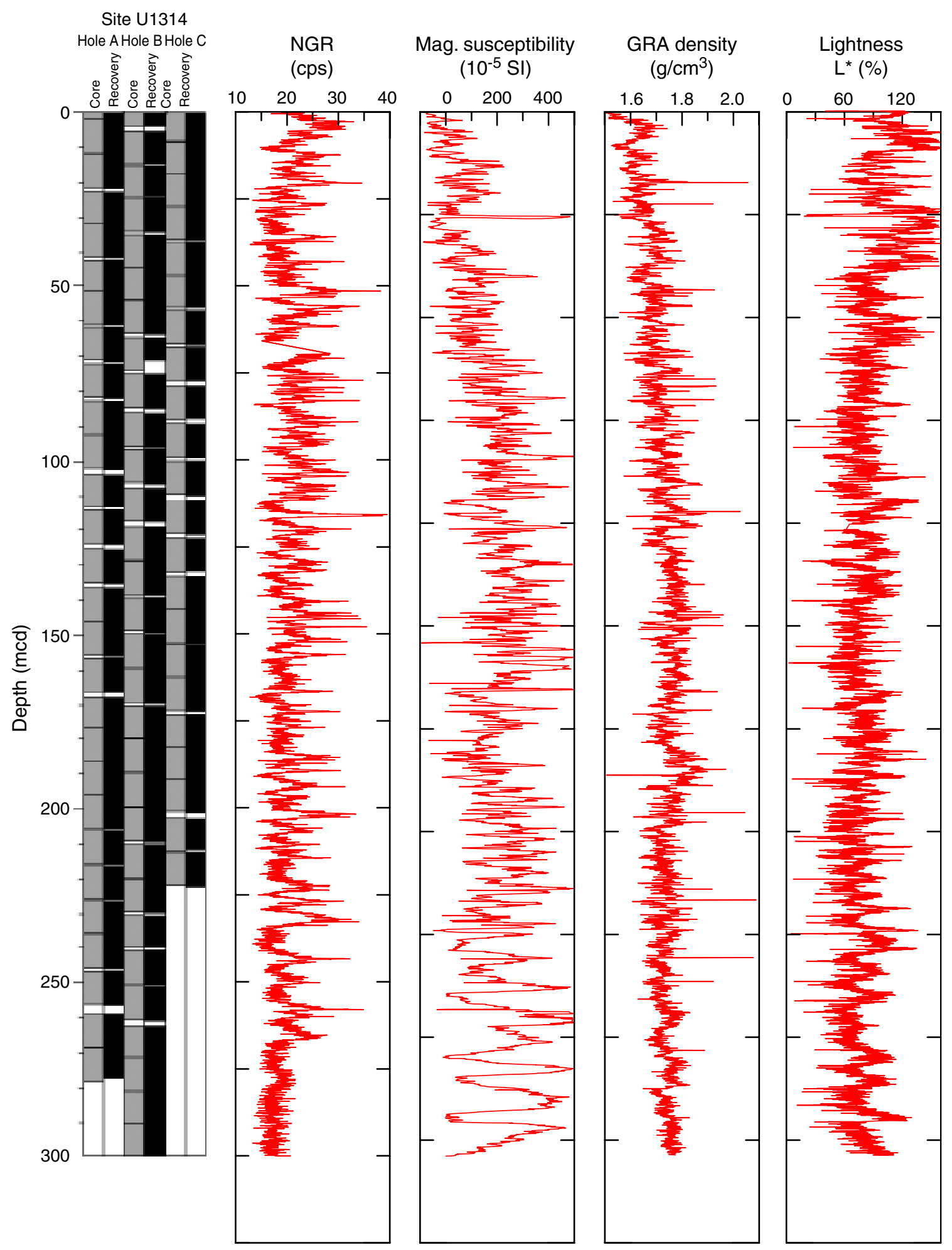


Table T1. Events and corresponding mcd depths used for Figure F5.

\begin{tabular}{|c|c|c|c|c|}
\hline \multirow[b]{2}{*}{ Biostratigraphic events } & \multirow[b]{2}{*}{$\begin{array}{l}\text { Age } \\
(\mathrm{Ma})\end{array}$} & \multicolumn{3}{|c|}{ Event depth (mcd) } \\
\hline & & $\begin{array}{c}\text { Site } \\
\text { U1312 }\end{array}$ & $\begin{array}{c}\text { Site } \\
\text { U1313 }\end{array}$ & $\begin{array}{c}\text { Site } \\
\text { U1314 }\end{array}$ \\
\hline LO Helicosphaera inversa & 0.16 & & 8.375 & \\
\hline FO Emiliania huxleyi & 0.25 & 13.47 & 19.105 & 25.565 \\
\hline LO Rhizosolenia curvirostris & 0.30 & & & 22.845 \\
\hline LO Pseudoemiliania lacunosa & 0.41 & 13.47 & 21.205 & 32.285 \\
\hline LO Fragilariopsis reinholdii & 0.50 & 20.565 & 34.505 & 39.35 \\
\hline FO Helicosphaera inversa & 0.51 & & 22.09 & 61.4 \\
\hline LO Fragilariopsis fossilis & 0.70 & & & 57.565 \\
\hline LO Neodenticula seminae & 0.84 & & & 65.27 \\
\hline LO Reticulofenestra asanoi & 0.85 & & 24.815 & 69.01 \\
\hline FO Gephyrocapsa parallela & 0.95 & 18.41 & 47.035 & 74.235 \\
\hline LO Stilostomella lepidula & 1.00 & & 47.035 & 87.37 \\
\hline FO Reticulofenestra asanoi & 1.16 & & 54.31 & 94.435 \\
\hline LO large Gephyrocapsa spp. & 1.21 & 22.775 & 51.815 & 94.435 \\
\hline FO Neodenticula seminae & 1.25 & & & 104.355 \\
\hline LO Helicosphaera sellii & 1.27 & 25.31 & 61.955 & 97.53 \\
\hline FO large Gephyrocapsa spp. & 1.45 & 31.96 & 79.4 & 126.535 \\
\hline FO Rhizosolenia curvirostris & 1.52 & & & 154.295 \\
\hline FO Gephyrocapsa oceanica & 1.65 & & & 150.73 \\
\hline FO Gephyrocapsa caribbeanica & 1.73 & 37.95 & 87.41 & 155.855 \\
\hline FaO Neogloboquadrina pachyderma (s) & 1.78 & & 83 & 157.71 \\
\hline LO Discoaster brouweri & 1.97 & 28 & 91.635 & 174.675 \\
\hline FO Globorotalia truncatulinoides & 2.08 & 39.15 & 99.965 & \\
\hline FO Globorotalia inflata & 2.09 & 39.15 & 108.94 & 184.815 \\
\hline LO Discoaster pentaradiatus & 2.38 & 28 & 110.695 & 232.9 \\
\hline LO Thalassiosira convexa & 2.40 & 52.28 & & 241.18 \\
\hline LO Globorotalia miocenica & 2.40 & & 107.11 & \\
\hline LO Neogloboquadrina atlantica (s) & 2.41 & & & 221.065 \\
\hline LO Globorotalia puncticulata & 2.41 & 55 & 103.66 & 222.94 \\
\hline LO Discoaster surculus & 2.54 & 40.7 & 121.04 & 253.365 \\
\hline FO Cycladophora davisiana & 2.59 & 56.525 & & \\
\hline LO Spongaster tetras & 2.60 & & & 272.955 \\
\hline LO Discoaster tamalis & 2.74 & 37.4 & 114.35 & 272.955 \\
\hline Disappearance Globorotalia hirsuta & 3.18 & 52.28 & 151.875 & \\
\hline LO Sphaeroidinellopsis seminulina & 3.19 & 56.525 & 147.445 & \\
\hline Reappearance Globorotalia puncticulata & 3.31 & 103 & 153.69 & \\
\hline Disappearance Globorotalia puncticulata & 3.57 & 112.48 & 164.09 & \\
\hline LO Globorotalia margaritae & 3.81 & & 183.77 & \\
\hline LO Reticulofenestra pseudoumbilicus & 3.85 & 117.8 & 172.87 & \\
\hline LcO Globorotalia margaritae & 3.98 & 124.49 & 185.67 & \\
\hline FO Globorotalia puncticulata & 4.52 & 144.155 & 214.85 & \\
\hline FO Globorotalia crassaformis & 4.52 & & 214.85 & \\
\hline LO Globigerina nepenthes & 4.89 & & 224.875 & \\
\hline FO Ceratolithus cristatus (rugosus) & 5.089 & & 242.15 & \\
\hline LO Discoaster quinqueramus & 5.537 & 173.05 & 251.94 & \\
\hline LO Amaurolithus amplificus & 5.999 & 184.265 & 320.285 & \\
\hline FaO Globorotalia margaritae & 6.00 & 181.5 & & \\
\hline Coiling change Neogloboquadrina pachyderma s/d & 6.30 & 173 & & \\
\hline FO Amaurolithus amplificus & 6.84 & 192.2 & & \\
\hline FcO gr Globorotalia miotumida & 7.24 & 191.5 & & \\
\hline FO Amaurolithus primus & 7.39 & 191.65 & & \\
\hline LO Globorotalia menardii 4 & 7.51 & 191.65 & & \\
\hline Coiling change Neogloboquadrina pachyderma $\mathrm{d} / \mathrm{s}$ & 7.80 & 188.63 & & \\
\hline FO Discoaster berggrenii & 8.28 & 200.955 & & \\
\hline FO Discoaster loeblichii & 8.43 & 214.63 & & \\
\hline LO Globorotalia lenguaensis & 8.99 & 210.915 & & \\
\hline FO Minylitha convallis & 9.43 & 224.07 & & \\
\hline LO Discoaster hamatus & 9.64 & 206.73 & & \\
\hline FO Discoaster hamatus & 10.48 & 252.615 & & \\
\hline FcO Neogloboquadrina pachyderma morphotype acostaensis & 10.50 & 252.615 & & \\
\hline LO Coccolithus miopelagicus & 10.95 & 252.615 & & \\
\hline
\end{tabular}

Notes: Dark blue $=$ nannofossils, pink $=$ foraminifers, light blue $=$ diatoms, orange $=$ radiolarians. Shaded events are not used in the calculation of sedimentation rates. $\mathrm{LO}=$ last occurrence, $\mathrm{FO}=$ first occurrence, $\mathrm{FaO}=$ first abundant occurrence, $\mathrm{LcO}=$ last common occurrence, $\mathrm{FcO}=$ first common occurrence. $d=$ dextral, $s=$ sinistral. 